\title{
CONVERGENCIA Y OFICIO ENTRE BALTASAR LOBO Y CLAUDIO RODRÍGUEZ (LA ALEGRÍA, EL IMPULSO Y EL VUELO)
}

\author{
CONVERGENCE AND FUNCTION BETWEEN BALTASAR LOBO AND \\ CLAUDIO RODRÍGUEZ (HAPPINESS, IMPULSE AND FLIGHT)
}

Luis RAMOS DE LA TORRE

Seminario Permanente Claudio Rodríguez / Asociación de Amigos de Baltasar Lobo (Zamora) valorio42@gmail.com

Resumen: En este artículo se trata de comprobar la cercanía y la convergencia que se produce entre la escultura de Baltasar Lobo y los versos de Claudio Rodríguez a partir de algunos conceptos esenciales: amor, moralidad, mejora, paisaje, materia, impulso, maternidad, casa, amistad, alegría... Aspectos que definen la obra y el oficio de estos dos creadores, en los que la presencia de la luz de las tierras zamoranas y el primer paisaje humano que vivieron serán algunas de las claves fundamentales para definir su modo de ver y de asumir lo artístico. Con ello se pretende aclarar las principales preocupaciones artísticas que rodean la cosmovisión y el oficio de cada cual, así como las líneas que definen las pautas a seguir en sus obras respectivas, ya sea desde el punto de vista del arte o desde la poesía. Líneas de acción creativa y conceptos que, a su vez, pueden dar lugar a la constatación de un mundo de convergencias y cercanías conceptuales, tanto de emoción como de motivación y creación, entre estos dos paisanos.

De igual modo, se analizan otros aspectos como la complementación de la levedad y la ingravidez presentes en su obra artística con la pesantez de la materia ofrecida al oficio de cada uno de ellos; la visión de dicha materia como algo sagrado y salvador; o la importancia crucial de la moralidad presente en su cosmovisión y en sus obras. Claves que les llevan a pensar en el creador y en su oficio dentro siempre de una tarea definida por la búsqueda de la mejora del hombre en todos los sentidos.

Palabras clave: Luz, amor, moralidad, mejora, paisaje, emoción, materia, impulso, maternidad, casa, amistad, alegría, levedad, pesantez, cercanía, convergencia, oficio. 
Abstract: This article looks to examine the closeness and convergence that exists between the sculptures of Baltasar Lobo and the poems of Claudio Rodríguez from a few essential concepts: love, morality, improvement, landscape, matter, impulse, maternity, home, friendship, happiness... Aspects that define the works and function of these two creators, among which the presence of light in the fields of Zamora and the first human landscape that they lived in will be some of the key components to define their point of view and artistic acceptance. From there, we shall try to clarify the main artistic preoccupations surrounding the worldview and the function in each of them, as well as the guidelines that define the rules that govern their respective works, be it from the point of view of art or from that of poetry. Lines of creative action and concepts that, in turn, can lead to the confirmation of a world of conceptual convergence and closeness, in emotion as well as in motivation and creation, between these two countrymen.

In the same manner, other aspects need be analyzed, like complementarity of the lightness and weightlessness present in their artistic work, and the weight of the matter offered to the function in each of them; the view of said matter as being sacred or salvation; or the crucial importance of morality that is present in their worldview and in their works. Key concepts that make them think of the creator and his function, always within a task that is defined by the search for the improvement of man in every sense.

Key words: Light, love, morality, improvement, landscape, emotion, matter, impulse, maternity, home, friendship, happiness, lightness, weight, closeness, convergence, function. 

n las siguientes reflexiones sobre algunos de los conceptos que definen la obra y el oficio de estos dos creadores, Baltasar Lobo y Claudio Rodríguez, en los que la presencia de la luz ${ }^{1}$ de las tierras zamoranas y el primer paisaje humano que vivieron serán algunas de las claves esenciales para definir su modo de ver y de asumir lo artístico, se pretende aclarar los motivos fundamentales que rodean la cosmovisión y el oficio de cada cual, y las líneas que han ido definiendo las pautas a seguir en cada una de las obras respectivas, ya sea desde el punto de vista del arte o desde la poesía. Líneas de acción creativa y conceptos que, a su vez, podrían dar lugar a un mundo de convergencias, tangencialidades y cercanías conceptuales, tanto de emoción como de motivación y creación entre estos dos zamoranos alejados en el decurso vital y temporal, aunque más o menos coetáneos.

\section{La importancia de la moralidad y el paisaje en el modo de ser hombre previo al artista}

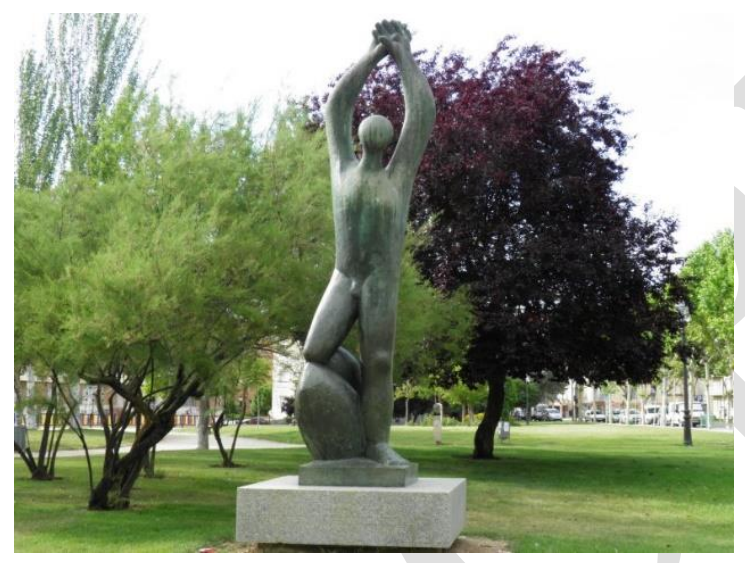

Antes de pasar a reflexionar sobre las características creadoras, artísticas o poéticas de nuestros dos protagonistas, es bueno que recordemos el modo de ser hombre de cada cual y analizar la forma en cómo la moralidad y el pensamiento actúan en la cosmovisión de cada creador; por ello es conveniente asumir con el filósofo Ortega y Gasset el hecho de que antes de hablar de un autor, sea el que sea, debemos tener en cuenta al hombre que hay detrás. Se trataría, pues, de considerar previamente al tipo de creador sobre el que vamos a hablar, la presencia de un hombre que sustenta la vida y la obra del autor en cuestión, pues como el filósofo madrileño recuerda hablando sobre Velázquez:

Cuando han dicho que un hombre es pintor se quedan con su pintar y dejan al hombre. Es lo que llamo la «falacia del atributo». Aplicamos a un sujeto un atributo, pero éste se nos vuelve león y se traga al sujeto sin que quede de él ni la raspa. [...] si es cierto decir de un hombre que es pintor, es mucho más cierto afirmar que ese pintor es un hombre y que lo es no sólo aparte de ser pintor, sino en tanto que pintor, pues pintar no es, en absoluto, otra cosa que otra manera de ser hombre. La tradición estúpida que coloca el arte en no se sabe qué región exenta y extravital tiene que quedar resueltamente desnucada. (Ortega, 1983, VIII: 49)

Estas palabras de Ortega nos sirven perfectamente de apoyo para indagar en los modos de ser hombre de estos dos zamoranos; así, vamos a comprobar como en ambos casos aspectos como el narcisismo nunca estará presente ni en sus apreciaciones, ni en las de sus estudiosos. Respecto de

\footnotetext{
${ }^{1}$ A partir de aquí, aparecerán en cursiva los términos compartidos por ambos creadores que sean relevantes para estas reflexiones.
} 
Baltasar Lobo, escultor, hombre siempre solidario, anarquista por convicción, de alta moralidad e implicado en las causas en favor de la igualdad en todos los sentidos, silencioso de raíz y dado a explicar en muy pocas ocasiones su forma de ser, de pensar y de trabajar, la profesora María Bolaños, especialista en su obra, ha escrito:

Conocemos mal los pormenores de su biografía, pero menos aún sus ideas sobre la escultura. No dejó escrito nada sobre su propia obra, concedió pocas entrevistas y cuando lo hacía no solía gustarle extenderse sobre sí mismo. No hay sino vagos testimonios sobre sus preferencias artísticas, sobre su formación personal, sus lecturas o sus gustos íntimos y las escasas declaraciones que poseemos se caracterizan por una parquedad, por lo demás muy zamorana, que con tal de no caer en la complacencia narcisista, prefiere pasar por una inexpresividad desesperante (Bolaños, 2000: 121-122).

Estas apreciaciones casan perfectamente con las del amigo del escultor y crítico Diehl, quien sobre Lobo explica: “Admiraba sobre todo su independencia silenciosa, pero insobornable, su laboriosidad exigente, su extremo sentido del material, el talento de su instinto, su familiaridad natural con los mitos (Diehl, 1985: 8-10)

De modo parecido, y en este sentido, el mismo Claudio Rodríguez en más de una ocasión dirá sobre sí: "Estoy fallando. No quiero hablar de mi biografía", lo que según su amigo el crítico y poeta Dionisio Cañas:

Descubre el pudor y la cautela con que este poeta ha actuado siempre respecto a convertir su vida privada en imagen pública" (Cañas, 1987: 8). Así mismo, en más de una ocasión el propio poeta hablará de la moralidad como algo necesario no sólo para la vida, sino también para su poesía: "La mía no es una ideología "de partido" sino una actitud moral. Uno piensa en la mejora del hombre, en combatir su degradación. Pero me estoy refiriendo a la conducta. Yo he afirmado siempre el sentido moral del arte (y últimamente he vuelto a planteármelo mientras trabajaba en la poesía de Miguel Hernández) y, en ciertos momentos, el poeta debe actuar ante la injusticia como cualquier persona. Puede hacerlo con una ideología previa o no. (Rodríguez, ed. Yubero, 2004: 233)

Sentido moral que Claudio Rodríguez se encargará de reafirmar en su Discurso de entrada en la Real Academia cuando abiertamente expone: "la poesía entraña moralidad, o sea, vida humana semejante al respirar y no ordenar por los predicadores sino por los poetas, como dice Shelley. El poeta necesita libertad" (Rodríguez, 1992: 22)

Moralidad necesaria para la vida y la creación que en ambos creadores se complementa con aquella referencia que dábamos al principio de estas reflexiones sobre la importancia que para ellos tendrá la presencia de la luz y el paisaje, ya que se trata de dos ejes necesarios desde donde focalizar, por ejemplo y en primer lugar, la forma de ser escultor y artesano de Baltasar Lobo, pues como nos indica la profesora Bolaños:

Si la idea orteguiana de que "un hombre es su región” fuese cierta en algún caso, lo sería sin duda en nuestro escultor, en cuyo carácter reconocemos el ascendiente que puede llegar a ejercer el ser de la tierra, adquirido sin necesidad de complicadas sabidurías, de manera natural, en una convivencia cuya calidad real entra por los ojos. Las escasas expansiones que sobre sí mismo se permite Lobo, escasez que es de por sí un signo, lo atestiguan: su concisa gravedad, su nulo gusto por las explicaciones, la seriedad con la que se tomaba todo, su resistencia a la abstracción, su desdén por la vida confortable y abundante..." [...] "no se puede desdeñar, sin faltar a la verdad, la presencia de los mudos parajes mesetarios, de sus hábitos y de sus habitantes, de su violenta sensualidad, que este emigrante se llevó apresados en la pupila de su memoria, 
donde perduraron siempre" [...] "esa tierra en suma en la que, según sus propias palabras "todo, la vida y el trabajo, resulta rudo y seco" (Bolaños, 2000: 24)

Tierra y paisaje esenciales para nuestro escultor compartidos con la experiencia de su gente, como la de su propia hermana, quien sobre este importante hecho explica:

Pues hay en la pupila oriunda de Tierra de Campos una sensibilidad para el tacto y lo tangible, para la materia y la masa de la que carecen otros "seres regionales", más propensos al visualismo puro, a las bellezas retinianas del esplendor vegetal" [...] "Habría entonces, por así decir, una atracción natural entre estas tierras y el mundo del escultor; un ámbito no cromático donde lo único que cuenta es el cuerpo a cuerpo con la materia, su voluptuosa tangibilidad" [...] "la atracción por la resistencia de la materia, por su encarnadura impenetrable, habría nutrido la vocación escultórica de Lobo - pues, al fin y al cabo, la escultura no es sino una modalidad de labranza-, cuando de muy niño comprueba cómo los duros terrones remojados por su propia orina despiertan en él un instinto de dominio infantil, que se vuelve una alegría posesiva a medida que la tierra se va transformando entre sus dedos en una masa blanda y obediente, gracias a ese poder mágico que tiene cualquier agua para unir la materia. (Lobo. V, 1995: 26)

Del mismo modo, la tierra ${ }^{2}$ y el paisaje, como recuerda el profesor Prieto de Paula, serán cruciales para la cosmovisión poética de Claudio Rodríguez:

Esta vinculación con el espacio empíreo no supone nunca desarraigo con lo terrenal; como en el mito de Anteo, la tierra da savia vital al hombre, que se eleva sobre sus limitaciones aprovechando esa gracia luminosa que llueve sobre él. Las imágenes con que nos la presenta el autor contienen, unas u otras, prendas cardinales de virtud: pureza de la lluvia, ardor de la llama, levedad aérea de la alondra. (Prieto de Paula, 1991: 167)

Pues, como dirá el propio Claudio Rodríguez, necesita:

[...] aclarar que mis poemas brotaron del contacto directo vivido, recorrido, con la realidad de mi tierra, con la geografía y con el pulso de la tierra castellana, zamorana" [...] Mal sabía, junto a mis pasos, que el paisaje y los hombres alentaban mis primeras andanzas o aventuras, y mi manera de escribir. (Rodríguez, 1984: 14)

Así, reconoce la importancia de la tierra natal y de los paisajes iniciales que conformaron su mundo; por ello, no es de extrañar que hablando de esto, y desde la obra de Miguel Hernández, aclare: "La convivencia con la naturaleza es sustancial porque es el descubrimiento de la vida. No es tan sólo el "color local" como se escribe despectivamente, ni de la tierra, sino del terruño, de la profunda “morada amarilla" (Rodríguez, 1992: 24)

Cosmovisión poética, pulso y caminar necesario de sus pasos a través del paisaje zamorano para descubrir y aprender con ello el ritmo y el impulso vital que surge de estas tierras: "Yo he escrito casi todos mis poemas caminando. Nunca en una mesa de trabajo. El hecho físico de caminar puede condicionar incluso el ritmo del poema. Eso era muy evidente en Antonio Machado. No es lo mismo contemplar las cosas andando que a gran velocidad" (Rodríguez, ed. Yubero, 2004: 6), porque nuestro poeta, al estilo machadiano, siempre se ha considerado un poeta andariego y caminante: "Cuando digo itinerario me refiero precisamente a que la mayoría de mis poemas (sobre todo los escritos en mis dos primeros libros) se realizan a través de una contemplación viva y andariega" (Rodríguez, 1983: 12)

Este modo de contemplar el paisaje y de participar de su ritmo natural, será bastante importante también en la concepción plástica de Baltasar Lobo; en este sentido, María Bolaños nos recuerda:

\footnotetext{
${ }^{2}$ Para ahondar en la importancia que tiene el concepto tierra en la cosmovisión de nuestro poeta puede consultarse "Tierra versus cielo: ¿caminos de salvación?”, Capítulo III.3.1 (Ramos de la Torre, 2017: 167 a 192).
} 
Víctima él mismo de esa "comezón andariega" que atacó a la juventud de su tiempo, lo que Menéndez Pidal llamaba "guadarramear", ve en el paisaje y en los pueblos españoles la mejor plasmación de lo que entienden como esencia nacional: nobleza, dignidad, orgullo, austeridad" [...] "su personal afán por conocer esa "geografía humana" le llevó a emprender un largo recorrido con una mochila al hombro, hacia 1934, para conocer directamente el mundo de los mineros, [...] animado por esa curiosidad etnográfica que resulta indistinguible de una idea casi religiosa del alma colectiva de lo popular. (Bolaños, 2000: 45-46)

\section{Del hombre al impulso creador: La materia y el oficio}

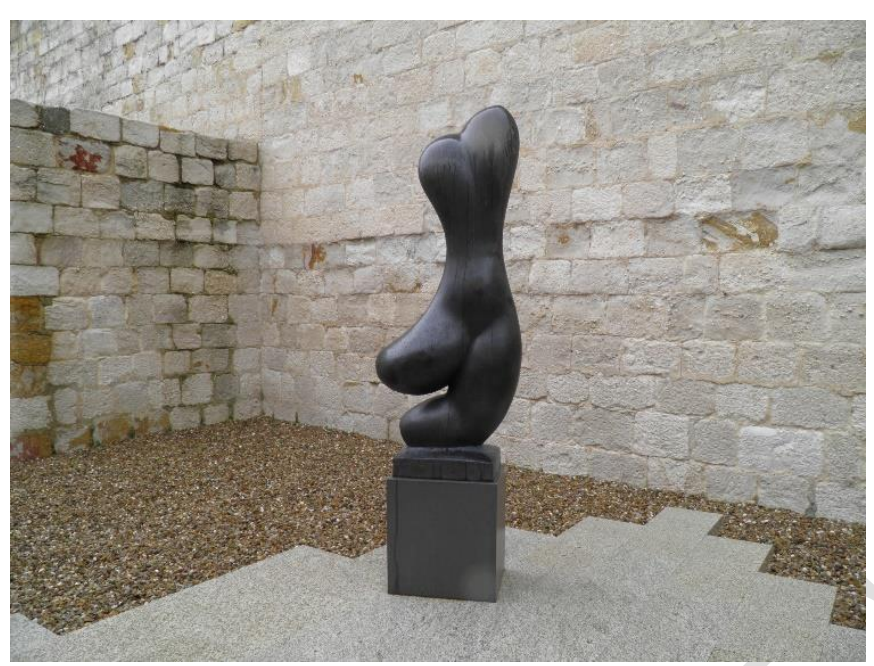

A partir de este carácter andariego de sus respectivos modos de entender la creación, y antes de avanzar en la reflexión sobre los conceptos fundamentales que justifican esta posible convergencia creadora entre ambos paisanos, es conveniente que hagamos constar cómo entendía el oficio cada uno de ellos, porque esta manera de asumir su tarea y de comprender su contexto creativo, ya sea al aire libre o en interiores, como si de un taller se tratara, caracteriza y explica todo lo que será su obra posterior. En el caso de Baltasar Lobo, -quien en más de una ocasión diría con rigor-: "No soy un artista. Yo tengo un oficio"-, es interesante recordar con María Bolaños que:

El joven Balta había aprendido desde casi un niño a entender la escultura como un oficio: había recibido de su padre el sentido profundo que esta palabra tiene, y también de su abuelo, que trabajaba en una tarea dura y humilde como la de cantero. Pero era tan celoso de la nobleza de este oficio como contrario a los narcisismos que tientan al artista. (Bolaños, 2000: 64)

Reflexiones que se completan con estas otras palabras de la misma especialista incluidas a modo de comentario en el reciente y esclarecedor Documental que sobre nuestro escultor se ha hecho para RTVE: "La Generación de Lobo recupera la artesanía, la relación con la materia, la talla directa [...] tratan de hacer una escultura más auténtica donde la huella de la mano esté más directamente expresada y esto lo vincula con Brancusi, Arp, Picasso" (Lobo, 2018). Modo de ver el oficio en Lobo que se complementa con estas otras palabras de la misma profesora:

La técnica además encajaba de perlas en su temperamento, con su idea de oficio. [...] Desde esta perspectiva, nuestro artista es uno de los ejemplos que a Bachelard le hubiese gustado tomar como modelo de su hipótesis, según la cual existe una correspondencia entre la creciente dureza de las materias trabajadas por un escultor y las necesidades psíquicas de sus edades. Y, desde luego, a uno no le cuesta mucho ver cumplida en Lobo esta fórmula geopsíquica de la maduración. (Bolaños, 2000: 130-140)

De igual modo, Claudio Rodríguez, sin olvidarse para nada de la técnica, y con su visión de la poesía y de la vida como participación, entiende éstas como proyección del hombre hasta abandonar casi su propia personalidad: 
El poeta debe dejarse robar por las cosas, pero sin dejar de estar activo, en la tensión entre el sujeto y el objeto: olvidarse y sumergirse en pleno territorio de la inteligencia, la intuición (la inspiración). Pero no sin la destreza, no sin el conocimiento del oficio. Por eso es absurdo que hablemos de poetas visionarios o iluminados como si no fueran, además, grandes técnicos. Yo me dejo llevar mucho por la inspiración (o la intuición), pero sin perder de vista mi oficio. La inspiración no es ciega (Rodríguez, ed. Yubero, 2004: 235)

También respecto de este punto, comprobamos que la técnica y el pulso de la mano para la talla, serán fundamentales en Baltasar Lobo, pues siempre estarán al lado de su inspiración, su imaginación creadora y su intuición ${ }^{3}$; no olvidemos que:

La imaginación material por decirlo así está siempre activa. No se satisface con la obra realizada. La imaginación de las formas descansa en su fin. Una vez realizada, la forma es rica en valores objetivos, tan socialmente intercambiables que el drama de la valoración se relaja. En cambio, el sueño de modelado es un sueño que conserva sus posibilidades. Ese sueño subyace en el trabajo del escultor. (Bachelard, 1947: 117)

\section{Y esto es así, porque como señala la profesora Bolaños:}

De ahí su naturaleza "prometeica" en los mitos clásicos, donde la tehcné indica un saber especializado que independiza a los hombres de las fuerzas divinas y les otorga un dominio de la materia a través de la fabricación de cosas. [...] la actividad de la escultura evoca la solidez de la constancia, la hermosa monotonía de la materia. (Bolaños, 2000: 225)

Dado que la materia, las cosas, van a ser quienes devuelvan al hombre, al creador, la imagen de lo que ansía como artista; Gaston Bachelard sobre esto nos recuerda que:

La materia es nuestro espejo energético; es un espejo que focaliza nuestras fuerzas iluminándolas con alegrías imaginarias. Y como en un libro sobre las imágenes sin duda se puede abusar de ellas, con gusto diríamos que el cuerpo duro que dispersa todos los golpes es el espejo convexo de nuestra energía, mientras que el cuerpo suave es el espejo cóncavo. (Bachelard, 1947: 34)

Pues de forma insistente, la materia (Ramos de la Torre, 2017), la realidad, los objetos, están llamando al creador, escultor o poeta, para que, desde su oficio, intervenga en ellos; así, será el propio Claudio Rodríguez (Ramos de la Torre, 2005: 509-518) quien en otro momento explique:

La realidad está ahí, fuera de nosotros, pero, vuelvo a decir, su resina, su horno, sus variedades concordes o discordes actúan junto a la imaginación y, sobre todo, con la levadura de la emoción. El poeta necesita, aunque no lo sepa, renunciar a su personalidad y, desde luego, a su originalidad. Quisiera entrañarse, identificarse con el objeto de su contemplación para renacer en él, para reconocerse en él. Se entrega y huye, se pierde y se encuentra a la vez, como renovado en el proceso poético, en la aventura de la visión, de la inspiración armoniosa. Lo cual no quiere decir irracionalidad, sino todo lo contrario, invención, en el sentido etimológico de descubrimiento, sorpresa. De ahí la vacilación radical en la que se encuentra el poeta. Si su misión, o su oficio es poseer, expresar un alma tangible aunque tan solo fuera por un momento para evitar su desaparición (como la de la nube que está allí: ¿cómo si no habitarla, pudiera a menos retenerla?), ¿cuál es esa presencia de las cosas sin unidad? (Rodríguez, 1992: 19)

\footnotetext{
${ }^{3}$ Es interesante anotar aquí como apoyo a la tangencialidad creativa que venimos comentando, la importancia de la relación de Baltasar Lobo con algunos poetas, sobre todo en el caso de los libros del alicantino y también poeta de la generación del 50, Francisco Pastor (1979 y 1981), que publicó ambos libros con Ilustraciones de Baltasar Lobo. Así, Guillermina Perales en Paco Pastor, un hombre de la cultura, Diario Información (Alicante, 22 de agosto de 2012), y sobre esta amistad escribirá: "Lobo pasó largas temporadas en Novelda, hasta casi el final de sus días. El escultor se enamoró del mármol rojo de Alicante y, por medio de Benjamín Palencia, conoció a Paco Pastor, quien le acondicionó un taller en su fábrica de Novelda, donde haría una magnífica producción artística".
} 
Vemos como, desde el impulso vital y frente a la materia sea ésta el lenguaje del poeta o la piedra que espera su talla, lo que resulte del proceso creador va a depender por completo de la emoción ${ }^{4}$ del hombre previo a la obra. A continuación, vamos a desentrañar la importancia que la emoción y la alegría ${ }^{5}$, como un ejemplo concreto de emoción clave, tienen para nuestros dos autores y la posible convergencia creativa entre ambos.

Para poder empezar a caminar y avanzar sobre todo esto, vamos a tener en cuenta, de manera axial, ciertas líneas de pensamiento marcadas por dos pensadores fundamentales en nuestra cultura como son Spinoza y Henri Bergson, ya que sus reflexiones sobre emociones y conceptos como el júbilo, la alegría o el impulso son esenciales para poder entender esa búsqueda de la felicidad creadora que aquí queremos desentrañar; no en vano el propio Bergson en La energía creadora definirá a este júbilo o alegría como "un signo de la creación misma que lo acompaña".

Como sabemos, y el excelente científico Antonio Damasio se ha encargado de recordarnos:

Spinoza consideraba que los impulsos, motivaciones, emociones y sentimientos (un conjunto que él denominaba afectos) eran un aspecto fundamental de la humanidad. La alegría y la pena constituían dos conceptos prominentes en su intento de comprender a los seres humanos y de sugerir maneras en las que estos podían vivir mejor su vida (Damasio, 2009: 14)

El propio Damasio y otros científicos como Giovanni Frachetto, a través de sus estudios sobre nuestros sentimientos y emociones, han querido aclarar que cuando los seres humanos procuramos la búsqueda de la mejora y de la felicidad:

Luchamos por un equilibrio -que en lenguaje científico se reconoce como homeostasis-, y nuestras acciones y nuestra conducta son movimientos que nos llevan de una experiencia a otra en pos de ese equilibrio del bienestar. La vida está tan llena de obstáculos como de razones para ser felices y estamos constantemente pasando de un tipo de situación a otra. (Frachetto, 2014: 233)

Ese modo de construir mejor la vida acercándola al mundo de la creación a partir de estos movimientos que, como iremos viendo en el caso de nuestros dos creadores, suelen ser de tipo ascensional, es aquel al que de igual modo se refiere el filósofo Bergson al hablar de la alegría:

Los filósofos que han especulado sobre el significado de la vida y sobre el destino del hombre, se han dado bastante cuenta de que la naturaleza se ha tomado el trabajo de informarnos sobre ello. Con una señal precisa nos advierte que se ha alcanzado nuestro destino. Esa señal es la alegría. Digo la alegría, y no el placer. [...] Pero la alegría siempre indica que la vida ha triunfado, que ha ganado terreno, que ha conseguido una victoria. Toda gran alegría tiene un acento triunfal. Si tenemos en cuenta es indicación y seguimos esa nueva línea de hechos, hallamos que donde quiera que hay alegría hay creación; cuanto más rica es la creación más profunda es la alegría. La madre que contempla a su hijo se siente gozosa porque tiene conciencia de haberlo creado psíquica y moralmente. (Bergson, 1982: 33-34)

\footnotetext{
${ }^{4}$ Este concepto, la emoción, es una clave en Baltasar Lobo, quien hablando de sus esculturas en el Documental para RTVE (Lobo, 2018) dirá: "Sí, te dan ganas de acariciar estas esculturas, porque sus formas corresponden más a la emoción”.

${ }^{5}$ Respecto a la relación escultura, materia y alegría, en el poema "Materia y alma" en "Esculturas (Bronces) de Tomás Crespo Rivera", Zamora, Caja de Ahorros Provincial de Zamora, diciembre de 1977, Claudio Rodríguez escribe: "Y cuando la materia se hace espacio / en la madera íntima, en el barro / temblando entre los dedos, llega el cobre, / aquí, / [ ...] / junto a la geometría intemporal, el límite / de la esperanza y del dolor del hombre, / con tanta soledad y con tanta alegría silenciosa // [...] La obra humana está aquí, entregada y dolida. / Y esta materia es alma, / ventana transparente: cuerpo y sueño. / Y abierta está. abrámonos. no hay noche / en el latido de este bronce en flor”.
} 
A partir de estas palabras es muy interesante observar la relación entre la alegría y la creación que comenta Bergson, porque este afecto spinoziano es altamente comprobable y vigente entre los motivos y conceptos que rodean la obra de nuestros dos paisanos, y, por supuesto, entre la escultura y la poesía. No en vano en la continua preocupación de Claudio Rodríguez por el mundo del arte. y en concreto por la escultura, en el poema "Monólogo del escultor", no incluido en libro canónico, pero que aparece como la cabecera del libro editado con motivo de la $8^{a}$ Bienal Ciudad de Zamora de 1986 dedicada a la Escultura Ibérica Contemporánea (Rodríguez, 1986: 27), leemos:

La materia es el alma, y no perdona.

$\mathrm{Ni}$ al bronce en flor de las campanas íntimas, ni a la madera aérea, ni al granito, ni siquiera a la piedra, con su ley, ni al hierro mal forjado, al barro, al níquel, al cuarzo, al mármol... Pero sí al volumen, [...] Quiero tocar, no ver tan solo, la mirada. Conocer con el tacto amanecido.

Estoy cantando entre materia ardiendo, que deslumbra y orienta, con geografía y pueblo. [...] Quédate quieto. ¿Y cómo voy a dar forma a lo que está fluyendo, a lo que se va y se queda para siempre? ¿Cómo voy a modelar, salvar este aire y esta agua, esta cultura que se me van, como se me está yendo la vida?

La materia está ahí, siempre esperando...

\section{La vigencia en lo artístico de la alegría y la infancia mejoradoras}

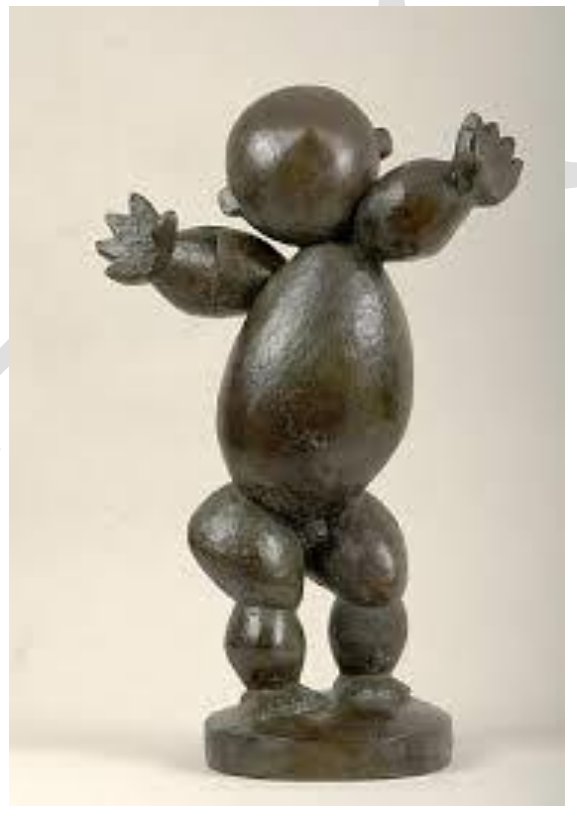

Desde aquí, y volviendo a los estudios de Giovanni Frachetto sobre la mejora producida en las acciones humanas por la presencia de un buen estado de ánimo, conviene considerar que: "Una lección importante que surge de los datos del laboratorio es que el humor positivo va ligado al logro de agudeza mental. Incluso una ligera elevación del estado de ánimo mejora nuestra capacidad de pensar y nuestra creatividad". (Frachetto, 2014: 240) Hecho que comprobaremos en la obra y las reflexiones de Baltasar Lobo y Claudio Rodríguez, y que se refleja en las palabras del profesor Frachetto:

Hoy se considera en general que un buen estado de ánimo mejora las habilidades para la resolución de problemas y el proceso creativo. Los científicos han probado el efecto de pensamientos positivos en la solución de problemas y tareas cognitivas, incluso en el caso específico de la asociación de palabras. (Frachetto, 2014: 244) 
Así pues, parece claro que la alegría trae asociada a su desarrollo la idea de entusiasmo, bienestar, impulso o felicidad que la hacen necesaria para un mejor ánimo a la hora de desarrollar el proceso creativo de cualquier poeta o artista. En este sentido, el profesor José Antonio Marina expone:

Si tuviera que elegir un estado de ánimo perfecto, me costaría decidir entre la alegría y el entusiasmo. Esto me hace pensar que entre ambos tiene que existir algún lazo subterráneo. Entusiasmo exhibe una etimología impresionante: en-theós. Sentirse como si uno estuviera habitado por un dios. Es una experiencia de energía, de vitalidad, de plenitud. La alegría tiene también esos componentes. Ortega y Gasset creía que está palabra derivaba de un término griego que significa "ciervo" y se preguntaba cómo había podido producirse esta relación. "Quien está alegre, salta, como los ciervos”, concluyó.” (Marina, 2012)

Tanto es así que: "La alegría, siempre que se lo permitamos, cuida de sí misma. Si encuentro una razón para estar alegre, por pequeño que sea el placer en cuestión, una nueva alegría se abrirá camino hacia mí por un atajo.” (Frachetto, 2014: 270), de ahí que seguramente ese atajo será fisiológico y, a su vez, emocional, equilibrador y animoso para el creador de acciones, sean éstas artísticas o no.

Por ello esta búsqueda (homeostasis) del equilibrio, de la felicidad y de bienestar hace que nos estemos moviendo, como decíamos más atrás, en el mundo de los impulsos; no en vano, Antonio Damasio nos recuerda que en el ser humano:

Está claro que el intento continuado de conseguir un estado de vida regulada positivamente es una parte profunda y definidora de nuestra existencia: la primera realidad de nuestra existencia, tal como Spinoza la intuyó cuando describió el esfuerzo inexorable (conatus) de cada ser para preservarse. Empeño, esfuerzo y tendencia son tres palabras que se acercan a la traducción del término latino conatus, según lo usa Spinoza en las proposiciones 6,7 y 8 de la Ética, parte III. [...] El conatus incluye tanto el ímpetu para la autopreservación frente al peligro y las oportunidades, como las múltiples acciones de autopreservación que mantienen juntas las partes de un cuerpo" (Damasio, 2009: 39-40)

Así, este conatus, este ímpetu, este impulso motivador produce un estado de elevación, de mejora, de alza, que parece tener mucho que ver con aquellas palabras de Claudio Rodríguez:

Y para ver hay que elevar el cuerpo, la vida entera entrando en la mirada. Llega el lenguaje como forcejeando entre sí, entre las puertas de la contemplación y las puertas del alma, con rebelión y con resurrección, como un aposento y un taller. Un impulso a ras de suelo o allá en el cielo que antes de que se efunda y de que cobre forma busca como alianza de ti, de mí, de las cosas." (Rodríguez, 1992: 18)

Al hilo de lo que comentábamos antes sobre la relación de la alegría y la creación en Bergson, es interesante recordar con Bachelard que:

[...] la poesía pone al lenguaje en estado de emergencia. La vida se designa en ellas por su vivacidad. Estos impulsos lingüísticos que salen de la línea ordinaria del lenguaje pragmático, son miniaturas del impulso vital. Un microbergsonismo que abandonara la tesis del lenguaje instrumento para adoptar la tesis del lenguaje-realidad, encontraría en la poesía muchos documentos sobre la vida completamente actual del lenguaje" (Bachelard, 1965: 19)

Sobre la importancia del impulso, que al lado de la levedad tendrá vigencia sobre todo en los primeros libros de nuestro poeta, Dionisio Cañas escribe: "Parto de la convicción de que el hecho poético es el punto donde se cruzan la línea de la vida del autor con un impulso en él a trascenderse. Es decir, que la poesía testimonia a la vez el querer ser (existencia) y el ser (trascendencia) de un escritor" (Cañas, 1987: 8). 
Sin pretender ser exhaustivos, porque no es esté el lugar para ello, resulta interesante considerar y constatar algunos momentos primeros de la presencia del impulso en la poesía de Claudio Rodríguez, por ejemplo en su primer libro Don de la ebriedad, donde leemos: "a la manera de los vuelos tuyos / y se cierne, y se aleja y, aún remota / nada hay tan claro como sus impulsos! (Libro Primero I)"; o en "Las imágenes, una que las centra / en planetaria rotación, se borran / y suben a un lugar por sus impulsos / donde al surgir de nuevo toman forma. (Libro Primero VI)". También aparecerá de forma interesante en su segundo libro, Conjuros, donde ya en el primer poema "A la respiración en la llanura" leemos: "Por eso la mañana aún es un vuelo / creciente y alto sobre / los montes, y un impulso a ras de suelo"; o en los versos de "A las estrellas": "Yo con mi impulso abajo y ellas siempre distantes". Vemos pues, como este concepto va a ser fundamental en su poesía, pues tal y como él mismo asegura: "la obra ha de nacer de la plenitud de la vida, no de una serie más o menos compleja de ideas abstractas que pueden agostar la lozanía del impulso emocional e imaginativo, o el de la intuición intelectual" (Rodríguez, 1987)

Así, esta elevación claudiana del cuerpo, este impulso, para ver dónde y cómo se alza el lenguaje hasta convertirse en poema, es similar a la que explica la actitud artística de Baltasar Lobo respecto de la estupenda serie de esculturas Élan (impulso), pues según María Bolaños:

Una indagación plástica de otra naturaleza es la que emprende en 1972, dando vida a un ciclo especialmente interesante, que se encuentra entre su obra más original, desarrollado al menos durante los siguientes diez años bajo el nombre genérico de Élan, un título bien expresivo pues describe el movimiento ascensional que libera al volumen de toda la dependencia de su armadura esquelética, sin dejar de respetar por ello su integridad cerrada. (Bolaños, 2000: 232)

Librándola, a la vez, de la pesantez de la piedra, añadiríamos nosotros.

Respecto de la liberación del volumen que comenta esta especialista el propio Lobo explica: ““'me he esforzado en proporcionar el máximo de luz y levedad a mis volúmenes para que estas imponentes piezas de mármol no resulten aplastantes, para que respiren en el espacio y sean resplandecientes"” (Bolaños, 2000: 236); porque para él, y según añade María Bolaños: “Respiración, esa es la clave. Pues no se olvide que la facultad que permite volar a algunos seres no deriva sólo de la posesión de alas, sino de sus pulmones, de la capacidad de inflar su volumen, estático y ligero, y ascender atravesando con alegre rapidez las masas aéreas”. (Bolaños, 2000: 236-237)

No vamos a entrar aquí de forma específica en un concepto tan fundamental para ellos como éste, la respiración ${ }^{6}$, que unido al impulso y el vuelo, es algo muy presente en la poesía del zamorano y altamente importante para nuestros dos creadores, pero conviene recordar, al menos de paso, su importancia, pues entre otras cosas para Claudio Rodríguez: “La participación con la naturaleza y con los hombres nos traspasa y nos impulsa con certeza no simulada como en tantos escritores. Leemos respirando vida" (Rodríguez, 1992: 26)

\footnotetext{
${ }^{6}$ Recuérdese, por ejemplo y en este sentido, la división en Claudio Rodríguez, realizada en sus cartas y conversaciones con Vicente Aleixandre respecto de su futuro tercer libro, Alianza y condena, entre poemas malditos y poemas inspirados, denominados más tarde como respirados. Sobre el tema de la respiración, Dionisio Cañas en el libro ya citado, página 58, escribe: "El concepto poético de respiración arranca de un hecho físico-emocional de orden corporal y telúrico".
} 
Sobre esta necesidad de vida respirada en ascenso y de forma contundente y clara, comentará en otro lugar María Bolaños:

La imagen de un impulso ascendente está inscrita desde muy pronto en la inspiración de Lobo". Así mismo, y sobre lo ascendente o el vuelo, será el propio escultor quien de forma emocionada y varias veces repetida, aclare: "Siempre he soñado en una escultura de mármol que sea como un vuelo, que se eleve sobre el suelo para brillar en medio de la luz, que nos haga olvidar la pesadez, la penalidad de la tierra. (Bonet, 2015: 16)

El impulso y el vuelo, el aire y la tierra, siempre la dualidad buscando una salida necesaria, por ello y respecto de la importancia de la relación entre lo telúrico y lo aéreo, es interesante comprobar como en la poesía de Claudio Rodríguez, aquella tierra de sus primeros paisajes, aquella levedad de la emoción y del impulso salvadores se va a ir transformando en piedra, en pesantez, que necesitará de un nuevo alzado (Ramos de la Torre, 2017: 282 -289), de nuevos poemas. Sobre esta necesidad de buscar la levedad y el alza a través de la poesía y el arte, constatada en ambos creadores, el novelista Italo Calvino explica:

Si quisiera escoger un símbolo propicio para asomarnos al nuevo milenio, optaría por éste: el ágil, repentino salto del poeta filósofo que se alza sobre la pesadez del mundo, demostrando que su gravedad contiene el secreto de la levedad, mientras que lo que muchos consideran la vitalidad de los tiempos, ruidosa, agresiva, piafante y atronadora, pertenece al reino de la muerte, como un cementerio de automóviles herrumbrosos. (Calvino, 1989: 24)

Esta ansia de levedad y de ingravidez, de huir de la pesantez de la materia, elevarla y elevarse con ella y en ella, será la que persiga Baltasar Lobo con sus torsos femeninos y sus maternidades, por eso Javier del Campo, buen conocedor de su obra, escribe:

Es más bien, un deseo de descanso intrascendente, como si hubiesen logrado encontrar un momento de suspensión y olvido en el que el escultor ha decidido eternizarlas. Así sucede, incluso, en sus torsos femeninos abstractos, que traducen, con una gran economía expresiva, la idea de suspensión aérea, de liberación de la sujeción terrestre. Una vez más, esta sublimación espiritual del fenómeno físico de la ingravidez está directamente endeudada con la sed de liberación que se extendió al final de la contienda como si la humanidad se hubiese dado a sí misma unas alas para alzarse del recuerdo de la reciente pesadilla. (del Campo, 2017: 35)

Después de todo esto, podemos decir que aquel conatus que veíamos en Spinoza, y este impulso, necesarios para la alegría, vista como un afecto esencial para equilibrar la vida, será crucial y estará muy presente también en sus vidas y su obra. Será el propio Baltasar Lobo quien, hablando sobre su modo de hacer, contará su experiencia crucial en la ciudad marítima de La Ciotat de la que dirá:

Fue mi reencuentro con la vida, allí me hice muy amigo de un pescador"7 [...] Yo trabajaba en lo alto de una torre que había sido un molino de viento, me la dejó un viejo. Era como una torre vigía. Desde el balcón más alto, se veía una playa pequeña, donde venían a pasar el día las familias, las madres con sus niños. Yo gozaba desde allí cuando se divertían y cómo los echaban a volar rodeados de agua, de sol, de arena... Me obsesionaba dibujar una y otra vez aquella escena [...] Era una alegría ver aquello, un mundo de felicidad, de maternidad, de esa emoción y de esas escenas nacieron mis esculturas que respiran placer al aire libre... (Lobo, 2018)

\footnotetext{
${ }^{7}$ Nótese como esta figura recuerda de algún modo al amigo de Claudio Rodríguez, Eugenio de Luelmo, personaje del poema del mismo nombre: "Que nació y murió junto al Duero".
} 
Según su mujer, Mercedes Guillén, y confirmado por él mismo, aparecen en su vida y su obra, una emoción y un impulso de entusiasmo fundamentales: "Creo que la escultura [...] debe contener algo más que un sentido puramente plástico, formal. [...] Las obras importantes realizadas en distintas épocas y países corresponden a una creencia que exalta y supera al hombre. Ante ella nos sentimos sobrecogidos por la emoción" (Guillén, 1960: 87), impresiones en Lobo siempre relacionadas con la alegría que le va a servir para contrarrestar las malas experiencias vitales y artísticas anteriores vividas en la época de la guerra europea:

Surgen así en los años cuarenta y cincuenta sus celebradas "maternidades", con las que será reconocido en los medios artísticos parisinos, jóvenes mujeres que juegan con sus hijos, los alzan o acunan. Una alegoría de la vida frente al dolor sufrido en las décadas anteriores de guerra y privaciones (del Campo, 2017: 9)

Vemos, pues, como a través de la alegría nuestro escultor avanza en la mejora de su vida y de su obra buscando un ir más allá, tanto de sí mismo como de la propia obra que está llevando a cabo. Conviene recordar que sobre el concepto de alegría y según nos recuerda José Ferrater: "para Scheler la alegría es «fuente y necesario movimiento concomitante»; no es un fin en sí mismo, pero acompaña necesariamente a la acción moral" (Ferrater, 1991: 86), quiere esto decir que la alegría marca un camino hacia delante; por esto mismo y en este mismo lugar, seguirá exponiendo que según el filósofo Vladimir Jankélévith. "la alegría surge cuando el alma desolada puede enfrentarse de nuevo con un futuro, es decir, cuando se le abre el horizonte [...] La alegría no pone límites; parecida al amor, quiere ir siempre más allá, a diferencia del goce o del placer”.

En estas palabras del pensador francés se puede observar también como la alegría, al igual que el amor, -conceptos, por otra parte, íntimamente relacionados en la poesía de Claudio Rodríguez-, tienen como objetivo común, ir "más allá"; esto es, procurar un avance en el camino que puede entenderse claramente, como hemos comentado más atrás al hablar de la presencia de la moralidad en nuestros dos creadores, como un proceso hacia la mejora del hombre. Esta mejora es connatural no sólo al estilo de ambos, sino al modo de entender la creación artística; por ello y en los dos casos, la presencia de lo sagrado será otra de las claves necesarias no solo para comprender su forma de hacer, sino de pensar y de entender la vida. El propio Baltasar Lobo repetirá una afirmación que sus amigos le oían decir con frecuencia, pues la vertiente artesanal de su ideal artístico es inseparable de su sentimiento "sagrado" de la escultura: “" "tengo una idea casi religiosa del arte"”:

Esta afinidad con lo sagrado era connatural en Lobo: "tengo un sentido, no diré religioso, pero sí sagrado de la escultura". No es un tema ocasional, ni una elección de estilo, sino una forma de entender la creación que compromete al artista hasta el fondo de sí mismo haciendo de ella una tarea sagrada, en tanto que representa un plano distinto de lo humano, una realidad de valores y exigencias absolutas que guía, como una religión, la totalidad del ser: "Creo en algo, -dirá también-, que no se puede abarcar" (Bolaños, 2000: 209)

Sobre la importancia de este concepto de lo sagrado en ambos, y más concretamente en Claudio Rodríguez, su amigo, estudioso de su obra y poeta Dionisio Cañas, explica: 
Claudio es un poeta de lo sagrado, no de lo religioso institucional; de la solidaridad con el hombre, no de la militancia partidista y sectaria. Su obra es un canto de lo humano general a través de su experiencia particular de la vida, no de la simplificación y reducción a que se somete la poesía al servicio de un partido o de un grupo literario. (Cañas, 1987: 51)

Esta diferencia de lo sagrado, que eleva y alza, con lo religioso se nos aclara aún más con las palabras del propio Claudio, quien en una entrevista explicará:

Lo que a mí me interesa es la salvación de la materia, la salvación de la realidad. No en el sentido religioso sino el salvar las cosas existentes, el elevarlas a cierto plano en el cual estén más claras, más limpias, más puras. (Hernández, 72: 12).

Palabras que concuerdan con las reflexiones del profesor Prieto de Paula, gran conocedor de su obra:

Este carácter sacro no consiste en un mero (y vacío) rodearse de gestos, liturgias, plegarias o rituales sino en dotar a lo vivido día a día, a tantos objetos humildes y conocidos, de una gracia nueva, oculta hasta este momento bajo la pátina de la costumbre, tras la corteza de lo habitual. (Prieto de Paula, 1980: 54)

Esa "gracia nueva" de las cosas que participa en ellas desde la poesía tiene que ver con la presencia crucial de la alegría. No en vano, en un momento fundamental para su vida y su obra, Claudio Rodríguez, en el poema "Lo que no es sueño" de su tercer libro Alianza y condena, y de forma totalmente clara y altamente reveladora, sobre la alegría escribe:

\author{
[...] Pero tú oye, déjame \\ decirte que, a pesar \\ de tanta vida deplorable, sí, \\ a pesar y aun ahora \\ que estamos en derrota, nunca en doma, \\ el dolor es la nube, \\ la alegría, el espacio; \\ el dolor es el huésped, \\ la alegría, la casa. \\ Que el dolor es la miel, \\ símbolo de la muerte, y la alegría \\ es agria, seca, nueva, \\ lo único que tiene \\ verdadero sentido. \\ Déjame que, con vieja \\ sabiduría, diga: \\ a pesar, a pesar \\ de todos los pesares \\ $\mathrm{y}$ aunque sea muy dolorosa, y aunque \\ sea a veces inmunda, siempre, siempre \\ la más honda verdad es la alegría."
}

Este concepto crucial, la alegría, va a aparecer en la obra de Claudio Rodríguez como una de las claves continuas de su poesía, pues como bien recuerda Carlos Bousoño en la respuesta al Discurso de entrada en la Real Academia de la Lengua del poeta zamorano:

Tanto Jorge Guillén como Claudio Rodríguez en sus dos primeras obras son ejemplo de algo que se ha dado poquísimo, al menos desde el Romanticismo, en la cultura occidental: incesante optimismo, alegría, entusiasmo por la realidad de las cosas y de la materia amén de las personas (Rodríguez, 1992: 57) 
Sobre esta alegría y este entusiasmo a la hora de escribir será el propio Claudio quien nos aclare:

Cuando comencé a escribir Don de la ebriedad tenía diecisiete años. Dos datos suficientes para orientar al lector. Poesía -adolescencia- como un don; y ebriedad como un estado de entusiasmo, en el sentido platónico, de inspiración, de rapto, de éxtasis, o , en la terminología cristiana, de fervor (Rodríguez, 1984: 14)

Entusiasmo por la materia necesario también para Baltasar Lobo, quien según F. Elgar:

Trabajaba con una enorme intuición, con una razonable lentitud, [...] y, como reconocen sus amigos, con una poderosa memoria visual, a la que añadía esa otra cualidad de los mejores escultores, la de "tener un compás en los ojos"” [...] Esta "superstición de la materia" compartida con Laurens, es primordial en su obra, $[. .$.$] cualidades conseguidas al precio de una entrega entusiasmada a la disciplina del oficio: "hay que$ verle desbastar, arañar, afinar, pulir el mármol francés, gris y duro, o el del Pentélico, blanco y dócil; hay que verle entretenerse en cómo transmite en una línea de pulsaciones de la sangre; hay que verle limar, adelgazar un volumen hasta que un leve abultamiento logra sugerirlo; hay que verle repasar la articulación de los planos mediante la inflexión de un contorno o de una arista viva...para calibrar hasta qué punto su voluntad escrupulosa y fuerte somete sus impulsos instintivos y las fiebres de la carne" (Elgar, 1962)

Este amor por el oficio, esta entrega entusiasmada, al lado de la alegría se transmitirá en sus obras, por eso no es extraño oír comentarios como los de otro paisano escultor más cercano en el tiempo a Claudio Rodríguez, José Luis Alonso Coomonte, quien sobre Lobo y en el Documental para RTVE ya citado explica:

En Baltasar Lobo hay armonía, hay musicalidad, hay silencio y además como en El hombre adámico -(escultura de gran tamaño dedicada al también poeta y paisano León Felipe-), hay elevación hacia lo divino. Toda la obra que hace Baltasar es feliz, el juego de una maternidad, de la madre con el niño. Es un hombre que es feliz, hace una obra que se quiere que se abraza, que se acaricia... (Lobo, 2018)

Siguiendo con la importancia de la alegría en Claudio Rodríguez, (paralela a los comentarios sobre Baltasar Lobo), vamos a pasar a revisar la presencia de este concepto esencial en los poemas de nuestro autor, donde comprobamos que su fuerza es mayor en los primeros libros, llenos de entusiasmo e impulso vital, que en los últimos, por el necesario tono meditativo que van tomando los poemas a lo largo de su vida, y debido seguramente al inexorable paso del tiempo. Así, de modo cronológico, vemos que está presente en su primer libro Don de la ebriedad, (Libro Primero III), donde leemos: “Así estoy yo. Qué encina, de madera / más oscura quizá que la del roble, / levanta mi alegría, tan intensa / unos momentos antes del crepúsculo", o más adelante en Libro Tercero, I: "he visto en el incienso de las cumbres / y en mi escritura blanca una alegría / dispersa de vigor. [...]. De igual modo en su segundo libro Conjuros, aparecerá en el poema "A las estrellas": “¿Tan miserable es nuestro tiempo que algo / digno, algo que no se venda sino que, alto / y puro, arda en amor del pueblo y nos levante / ya no es motivo de alegría? [...]" (Rodríguez, 1984: 35)

En los versos anteriores la alegría se presenta, según vemos, al lado de otros dos conceptos esenciales, tanto para Baltasar Lobo como para él, la altura y la necesidad de elevación; tanto es así que en nuestro escultor y según explica María Bolaños:

[...] en el reino de la imaginación, la libertad es una alegría aérea, la plenitud espiritual, una ascensión; la dignidad de los hombres libres, una levitación imaginaria: el hombre quiere crecer, busca instintivamente la altura, ansía conquistar el cielo" [...] "la madre-pájaro que enseña a volar a su cría junto al nido...; todas 
ellas, aún sometidas a vidas inllevables, de fracaso y derrumbamiento, esconden moralmente victoria y deseos de ascensión (Bolaños, 2000: 225)

Apreciaciones que coinciden con las reflexiones del filósofo francés Gaston Bachelard, quien sobre el impulso y la altura expone:

En el viaje a la altura, el impulso vital es impulso hominizante, o sea, en su tarea de sublimación discursiva los caminos de la grandeza se constituyen en nosotros. Ramón Gómez de la Serna ha dicho que en el hombre todo es camino. Hay que añadir: todo camino aconseja una ascensión. El dinamismo positivo de la verticalidad es tan claro que podemos afirmar este aforismo: El que no asciende, cae. El hombre como hombre, no puede vivir horizontalmente (Bachelard, 1958: 21)

Acorde con todo esto, y en los versos del poema "A las puertas de la ciudad”, Claudio Rodríguez escribe: "[...] ¡Si era claro: / tanta alegría por tan poco costo / era verdad, era verdad! Ah, cuándo / me daré cuenta de que todo es simple." [...] “[...] ¿qué otra cosa haríamos / sino tender nuestra humildad al raso, / secar al sol nuestra alegría, nuestra / sola camisa limpia para siempre?”. O en el maravilloso poema "Alto jornal" en el que la importancia del oficio aparecerá como algo esencial para él: "anda y siente subirle entre los pasos / el amor de la tierra, y sigue, y abre / su taller verdadero, y en sus manos / brilla limpio su oficio y nos lo entrega".

Importancia del oficio igualmente esencial para Baltasar Lobo, quien en más de una ocasión expondrá a su hermana de manera categórica que él no era "ningún artista", que "su oficio era ser artesano"; así, respecto de la alegría en el poema anterior, leemos: "vuelve a su casa alegre y siente que alguien / empuña su aldabón y no es en vano".

Los siguientes versos en los que aparecerá la alegría están en "Incidente en los Jerónimos", donde de nuevo la presencia de la altura, los pájaros y el vuelo serán tan esenciales como sucede en toda la poesía de Claudio Rodríguez en la que las aves y los pájaros: el gorrión, la paloma, la alondra y las golondrinas, entre otros, serán fundamentales, no sólo por su simbología, sino también por la emoción salvadora que produce su presencia. No en vano, y sobre este tema, será de nuevo Bachelard quien nos aclare:

Puede decirse que, en el reino de la imaginación creadora aérea, el cuerpo del pájaro está hecho del aire que lo rodea, su vida del movimiento que lo arrastra. [...] La imaginación de Toussenel une directamente la pureza del aire con el movimiento alado: "El pájaro, creado para vivir en el elemento más sutil y más puro, que es necesariamente, entre todos los modelos de la creación última, el más independiente y más glorioso (Bachelard, 1958: 90)

Sobre la importancia de los pájaros en particular y de los animales en general, el propio Claudio Rodríguez explica:

El poeta "ve", pero también "imagina", y no le importa casi siempre la descripción anatómica de los diversos animales ${ }^{8}$. Convive su presencia, la energía del ser, por encima de los límites de la forma. [...] Claro que la integración de la fauna es sustancial (singularmente a partir de ciertos territorios surrealistas) en la configuración, los quicios y el vuelo del espíritu humano y, por consiguiente, de su expresión. Sueño, amor,

\footnotetext{
${ }^{8}$ En esta presencia necesaria de la animalidad en la poesía, Claudio recuerda también: "el gato de Baudelaire, con sus "pupilas místicas"; el tigre de Blake; la alondra de Shelley, "espíritu o pájaro"”; el ruiseñor de Keats; la calumniada abubilla de Montale...".
} 
aspiración hacia la luminosidad, hacia la terrible libertad oscura de las criaturas...Hacia la forja de los abismos. Como escribía Aldana: el del “aéreo desdén” (Rodríguez, ed. Yubero, 2004: 201)

\section{Del mismo modo, la presencia de estos conceptos en Baltasar Lobo: el vuelo y los pájaros,} complementarios de la alegría, será fundamental como estamos viendo en toda su escultura:

[...] el ave encarnaba para él la idea de la fuga voladora que se convertirá en un topos recurrente de su estilo [...] Pero en la predilección esconde otra analogía, según la cual el pájaro representa la máxima condensación de vida, un modelo de ser en su más alto grado de unidad. El pájaro posee ese exceso de concentración vital que esconden todos los seres libres, y que en contrapartida hace de ellos individualidades aisladas, seres solitarios de extrema debilidad social. No es muy probable que Lobo conociese el texto clásico de Jules Michelet, ${ }^{9}$ L'oiseau, donde ese escritor francés reconoce en este volador casi esférico, a "la criatura única, el árbitro de todas las demás, el enlazamiento de todas las vidas, la conciliación de los seres", pero es admirable la coincidencia entre la interpretación plástica de uno y la literaria del otro en la visión de esta especie animal como una imagen cósmica, como una acumulación de vida absoluta, encerrada en una bola, fuerte, aislada y frágil a la vez. (Bolaños, 2000: 186-187)

Tanto es así, que sobre estos aspectos y después de reflexionar sobre su importante papel en la obra de Lobo, la propia profesora nos aclara:

Lobo dedicó a las aves que vuelan algunas de sus esculturas de los años cincuenta: gaviotas, palomas y pájaros genéricos aparecen en un momento dado de su biografía artística que viene a coincidir con una época en la que el vuelo se convierte en un tema particularmente atractivo para los escultores que lo tratan con una frecuencia inesperada. (Bolaños, 2000: 227)

Pero se trata de una idea de vuelo centrada en la fuerza de la animalidad que viene a coincidir con su interés por incluir este matiz de lo animal en sus esculturas femeninas:

[...] la morfología femenina es en Lobo un gran depósito que lo acoge todo: los principios cosmológicos y los accidentes de la geografía, como el viento, el levante o el río; los ritmos de la naturaleza que germina: el alba, el vuelo, el despertar, la mañana, el manantial, la brisa; o inversamente, la vida quieta: el reposo, la siesta, la caída." [...] "Por ello son también, en último término y por usar sus propias palabras, un requerimiento de libertad. [...] Hay, pues, en sus diosas y en sus torsos una suerte de "animalización" [...] que había asumido como una aventura nueva, ese "animalismo instintivo", de ambivalencias surrealistas, de exaltación del instinto y la fecundidad de las fuerzas telúricas más amables, que pone en entredicho la convención anatómica aprendida." [...] "Comprensión animalizada del cuerpo de la que derivará asimismo su atracción por los monstruos, por los híbridos animales... (Bolaños, 2000: 159-160)

Porque desde el vuelo, el pájaro, o el interés de lo animal o lo fáunico fijado en sus esculturas y en el cuerpo femenino, Lobo buscará, como ya se ha visto, la totalidad del mismo modo que Claudio Rodríguez ${ }^{10}$ cuando en este sentido reflexiona:

Y es que el poeta busca la totalidad, la infinitud, en contienda con la transformación, no tan solo del tiempo, sino también del espacio: del espacio de su intuición, que no es el espacio real. ¿Y qué más

\footnotetext{
${ }^{9}$ La cita del estudioso francés se refiere a Michelet. J., L'oiseau, París, Jacques-Marie Laffont, 1982, pp.381-383. Nótese, como no deja de ser sorprendente que esta coincidente interpretación del concepto de absoluto, de totalidad y de máxima condensación de vida desde el ave, que aparece en la cita: "El pájaro posee ese exceso de concentración vital que esconden todos los seres libres" y en: "la visión de esta especie animal como una imagen cósmica, como una acumulación de vida absoluta", recuerda también la visión que aparece en el poema de Claudio Rodríguez "Gorrión" de su tercer libro Alianza y condena, cuando escribe: "Ya dio al aire a los muertos / este gorrión, que pudo / volar, pero aquí sigue, / aquí abajo, seguro, / metiendo en su pechuga / todo el polvo del mundo."

${ }_{10}$ Para ello, recuérdense nuevamente los versos del poema "Gorrión".
} 
insondable espacio que el de la fauna, -pájaro o aves en este caso- con su inconmensurabilidad? (Rodríguez, ed. Yubero, 2004: 201)

Qué cercanas estas reflexiones a las del filósofo francés Gastón Bachelard cuando sobre el tema de lo aéreo explica: "las imágenes poéticas son operaciones del espíritu humano en la medida en que nos aligeran o nos levantan o nos elevan. No tienen sino un eje de referencia: el eje vertical. Son esencialmente aéreas" (Bachelard, 1958: 57)

Así, volviendo de nuevo a la revisión del concepto alegría en la poesía de nuestro autor y en el poema que nos ha servido de guía para estas reflexiones sobre la relación entre la jovialidad y el vuelo, "Incidente en los Jerónimos", leemos lo siguiente: "tú recuerda, recuerda / la fugaz alegría / de los hombres, su fiesta / tan pobre en días y tan rica en tiempo". Más adelante, en "La contrata de mozos" de nuevo al lado del sol y de la sencillez aparece: "Es tan sencillo, da tanta alegría / ponerse al sol una mañana hermosa, / pregonar nuestro precio y todo cuanto / tenemos de hombres darlo a la redonda"; de igual modo, y con este sentido de fiesta, de ofrecimiento y de oficio, aparecerá en "El baile de Águedas": "Ya están ahí, ya vienen / por el raíl con sol de esperanza / hombres de todo el mundo. Ya se ponen / a dar fe de su empleo de alegría. / ¿Quién no esperó la fiesta?”. Y finalmente, en "Pinar amanecido" último poema de este segundo libro, la alegría se mostrará al lado de otra de las preocupaciones claves de la obra de nuestros dos creadores que analizaremos de paso y a continuación, el mundo de lo infantil, los niños: “¿Un paso al frente el que ose / mirar la faz de la pureza, alzarle / la infantil falda casta a la alegría!".

Respecto de lo infantil y según los comentarios de muchos de sus amigos, es muy clara la querencia de Baltasar Lobo, tanto en su vida como en su obra, por los niños y la infancia, posiblemente por causa dos factores claves, el excesivo número de muertos y la desolación posterior tras la guerra, por una parte:

Se respira en el ambiente como un ansia de repoblar esa tierra desolada por la guerra, al mismo tiempo de alegría de vivir, un continuo canto a la vida, renacer, perpetuarse, reproducirse y una insistente interrogación sobre la condición del hombre. Todo esto está reflejado en la obra de Lobo de una manera evidente, casi también obsesiva. (Vázquez Parga, 2009)

Y debido al hecho terrible de que su esposa Mercedes, enferma por tantos sufrimientos vividos, no pudiese concebir hijos:

Su simpatía por los niños era una constante que todos sus amigos recuerdan, destacando en particular el afecto por los hijos de sus allegados. [...] Ese afecto secreto afloraba en su colaboración desinteresada con asociaciones de protección de la infancia, como, por ejemplo, la donación de alguna escultura a la Comisión Central de la Infancia. (Bolaños, 2000: 163-Nota 4)

No deja de ser curiosa esta misma forma de pensar y la coincidencia con Claudio Rodríguez en quien el amor por los niños y la presencia de la infancia es una constante continua en su obra en prosa y en verso:

Es en el plano del ensueño, y no en el plano de los hechos donde la infancia sigue en nosotros viva y poéticamente útil. Por esta infancia permanente conservamos la poesía del pasado. Habitar oníricamente la 
casa natal, es más que habitarla por el recuerdo, es vivir en la casa desaparecida como lo habíamos soñado. (Bachelard, 1965: 46-47)

Desde esta óptica, son varios los estudiosos de la obra claudiana los que han reparado en este aspecto $^{11}$, pero dada la cercanía con nuestro poeta y la amistad entre ambos, las declaraciones de Dionisio Cañas en este sentido nos parecen fundamentales:

Claudio y Clara no tienen hijos. Los niños son, pues, una ausencia para la vida de la pareja y, a la vez, se alza la infancia como un tema poético muy importante en la obra del autor. Aquí de nuevo la vida y a literatura se ligan, en este caso de una forma muy pendular. Por un lado la infancia es un tema poético de antigua raigambre; por el otro, se eleva casi a nivel de culto por ser algo inalcanzable para la pareja. El poeta se sitúa ante los niños en una actitud de espectador: esto es a la vez una perspectiva poética y una forzosa realidad vivencial. Para Rodríguez los niños son los legítimos poseedores de la inocencia del mundo y, por su sola existencia, salvan (como la poesía) al ser humano (Cañas, 1987: 45-46)

Tanto es así, que será el mismo poeta quien en una emisora de radio zamorana asegure: "Yo no creo, por tanto, que la infancia se pierda, al menos no en los grandes creadores. Y no estoy hablando de nostalgia, por decirlo así, del paraíso perdido, de la inocencia perdida, que tantos poetas han cantado." (Iglesias, 1989)

Siguiendo con la presencia del concepto alegría en la obra de Claudio Rodríguez, y ya en su tercer y gran libro Alianza y condena, aparecerá de forma menos sustantiva y en un tono bastante más meditativo y menos cercana a la fiesta, aunque sí próxima a la celebración, en el poema "Gestos": "Nosotros, tan gesteros pero tan poco alegres", o en "Cáscaras": "[...] las cuatro copas / que nos alegran al entrar en esos / edificios donde hay sangre y hay llanto". También, pero ahora de forma interrogativa la vemos en "Por tierra de lobos”: “¿Cómo podrás ahora / acompasar deber / con alegría, dicha / con dinero? Mas sigue.”En este mismo poema aparecerá de nuevo, y de forma muy interesante, al lado de la infancia: "Aquellas niñas que iban al colegio, / de ojos castaños casi todas ellas, / aún no lejos del sueño y ya muy cerca / de la alegría. [...] Erguido sobre / tantos días alegres, / sigo la marcha. [...]". La importancia de este concepto se nos aclara aún más cuando en el poema clave ya citado "Eugenio de Luelmo", dedicado a un personaje fundamental para Claudio Rodríguez (Que nació y murió junto al Duero), -al estilo del pescador francés de La Ciotat amigo de Baltasar Lobo -, nuestro poeta definirá la alegría e forma categórica y salvadora como "la única justicia": "flor y fruta a la vez, y muerte, y nacimiento / al mismo tiempo, y ese gran peligro / de su ternura, de su modo de ir / por las calles, nos daban / la única justicia: la alegría."

De igual modo, al lado de la carencia y la necesidad, la observamos en "Dinero": “[...] No plaga, lepra /como hoy; alegría, / no frivolidad; ley, / no impunidad. [...]”; y de nuevo relacionado con el hecho de alzar la vida, en el poema "Un olor": “[...] Pero ahora / este tesoro, este / olor, que es mi verdad, / que es mi alegría y mi arrepentimiento, / me madura y me alza.”. No olvidemos que la altura, el alzado y el impulso serán fundamentales para lograr la luz y la claridad, pues, en ambos creadores y cómo recuerda Bachelard en sentido general:

${ }^{11}$ Para este tema, véanse entre otros: (Rodríguez, 1988); (Ramos de la Torre, 2004 en Archipiélago: 73-78); (Ramos de la Torre, 2004 en Revista de Literatura: 61-69) 
Las imágenes se vuelven oscuras o vanas para un lector que se niega al impulso poético, muy especial, que las suscita. Y, al contrario, una imaginación simpáticamente dinamizada las encontrará vivas, es decir, dinámicamente claras. Porque podemos hablar de una claridad y de una distinción dinámicas. Dicha claridad y dicha distinción dinámicas corresponden a intuiciones dinámicas naturales y primeras (Bachelard, 1958: 62)

Luz y claridad tan cercanas siempre a ambos y a su concepto de alegría; por ello, tal y como reconoce María Bolaños, uno de los motivos escultóricos fundamentales para Baltasar Lobo será esta alegría asociada al mundo de las mujeres, de las madres y de los niños ${ }^{12}$, de la infancia en suma:

Poco antes de morir, respondiendo a un periodista que le preguntaba sobre el significado de uno de sus recientes desnudos - una mujer con los brazos en alto-, este octogenario revelaba que seguía dependiendo emocionalmente de su experiencia vital de estos años amargos: "esta figura representa la alegría de haber pasado todos los horrores de la guerra, de la lucha fratricida; está expresando, en una palabra, la libertad perdida en las calamidades de la guerra"". [...] "Esta interiorización de su experiencia vital es la clave de su naturaleza artística y de lo mejor de su obra (Bolaños, 2000: 85)

De igual modo, y como ya venimos intuyendo en "Oda a la niñez" Claudio Rodríguez asociará ambos conceptos: “ ¿Y esta es tu bienvenida, / marzo, para salir de casa alegres: / con viento húmedo y frío de meseta".

Según hemos comentado más atrás, y debido al uso de un tono más reflexivo y meditativo, en su cuarto libro, El vuelo de la celebración, libro que comenzará con el durísimo poema "Herida en cuatro tiempos", la alegría aparecerá al lado del dolor o del miedo en poemas como "Cantata del miedo": "Y es que en él hallaríamos el suspiro inocente, / el poderío de las sensaciones, / la cosecha de la alegría junto a la / del desaliento"; o al lado del amor en "Noviembre": "Tras tanto tiempo sin amor, esta mañana / qué salvadora. Qué / luz tan íntima. Me entra y me da música / sin pausas / en el momento mismo en que te amo / en que me entrego a ti con alegría”. El mismo júbilo, la misma alegría que veremos relacionados con la mirada y las emociones en "La contemplación viva": "con tanta sencillez emocionada / que me deja y me da / alegría y asombro, / y sobre todo, realidad"; o unido a la voz amada en "Voz sin pérdida": "con sus tonos astutos, tierna y seca, latiendo / tan desnuda que limpia la alegría". Pero esta alegría tan reveladora y salvadora, aquella "verdad más honda" a la que se refería en el clarificador "Lo que no es sueño", aparecerá ahora como gran verdad y conocimiento ya casi al final de El vuelo de la celebración, en el poema "Salvación del peligro": "con la alegría del conocimiento".

En jaque con el tiempo de la vida y con la alegría como una de las marcas conceptuales de sus versos, aunque ahora, como ya hemos dicho, más meditativa y reflexiva, la última poesía de Claudio Rodríguez en Casi una leyenda, su quinto y último libro canónico, se va a caracterizar por una sacralización de la materia a partir de la conciencia de la muerte. No olvidemos la importancia que

\footnotetext{
${ }^{12}$ Es interesante recordar que: "Lobo realizó a lo largo de su vida numerosas variantes de estos encuentros madre-hijo. Las versiones que podemos llamar "aéreas", con el niño alzado son las dominantes. Mujeres jóvenes, exuberantes y robustas componen una figura, única y dúplice a la par, que emana tanto ternura como júbilo" [...] Pero nada debe distraernos de la verdadera intención de nuestro artista: la celebración de la felicidad y acaso, también, una cierta melancolía ante la imposibilidad de concebir un hijo con su compañera Mercedes Guillen, cuya salud quedó seriamente quebrantada durante la Guerra Civil y el primer exilio.” (del Campo, 2017: 14)
} 
este último concepto tiene para nuestros dos artistas, pues en Baltasar Lobo es fundamental para entender no solo su estilo sino todo el desarrollo de su modo de entender el arte y la escultura. Será de nuevo María Bolaños quien nos aclare:

\begin{abstract}
Cuando llegó a París, con el espíritu trastornado por la experiencia, le era imposible librarse de las escenas vividas: "No podía dormir. Era un delirio continuo. Todo lo que había vivido me obsesionaba, me perseguía. Era espantoso. Todo lo que había visto, todo lo que había sufrido, todo lo que yo había hecho..." [explica nuestro escultor]" [...] "Es en esta convivencia donde se forjará un rasgo de su carácter que no podría calificarse exactamente de pesimismo, pero sí de un sentimiento muy arraigado de la inevitabilidad de la muerte, un sentimiento que yace escondido en el último trasfondo de su escultura, en su condición inquieta y despegada. [...] Lobo, que sufrió tantas tinieblas y calamidades, se forjo este tipo de carácter sobriamente animoso que da el saber que la muerte es un ingrediente de la existencia, y que la mejor manera de gestionarla es afrontar la vida con un ánimo combativo, que para él equivalía a trabajo, disciplina y dedicación al oficio (Bolaños, 2000: 51)
\end{abstract}

Sentimiento y conocimiento de la muerte y de las pérdidas que definen lo vital y el desarrollo creativo, y que al lado de la alegría salvadora darán relevancia también especial a los poemas de este último libro de Claudio Rodríguez. Así pues, esta alegría necesaria aparecerá en principio sujeta a las pérdidas de la vida en "Nocturno de la casa ida": "y que me dio serenidad y ahora / tanta alegría prisionera! [...]", pero que a pesar de la oscuridad, de la pesantez de la vida y del tiempo yéndose, se irá aclarando en "Nuevo día" para dar conocimiento al poeta: "Es la iluminación de la alegría / con el silencio que no tiene tiempo", hasta llegar a ser comienzo y gran parte del poema de amor salvador ““"The nest of lovers"”: "Y llegó la alegría / muy lejos del recuerdo cuando las gaviotas" [...] "toca con alegría y con pureza" [...] "cuando ahora vivo la alegría nueva, / muy lejos del recuerdo, el dolor solo, / la verdad del amor que es tuyo y mío".

Aunque la presencia del amor es crucial en todos sus libros, el cuerpo de la mujer y la corporalidad aparecerán en los últimos de forma importante y gradual, mostrando el concepto de lo corpóreo junto a la alegría en poemas como "Momento de renuncia": "llega el placer de todos los sentidos, / y la visitación de Benavides, / y la alegría de la carne, el puro / cuerpo festivo, cuando canta el gallo / a lo oscuro, / y el trino ágil del pezón moreno". Y, de nuevo, veremos lo jubiloso al lado de la dicotomía entre la claridad y la noche verdadera en "Un brindis por el seis de enero": "Viene la claridad que es ilusión, / temor sereno junto a la alegría recién nacida / de la inocencia de esta noche que entra"; juego dual que se mantendrá en el siguiente "Balada de un treinta de enero": "tanta alegría hacia la claridad, / tanta honda invernada. / Y el cuerpo en vilo / en la alta noche que ahora". En el último poema del libro, "Secreta", que habla específicamente de la muerte, terminará, a pesar de todo, hablando de la alegría, de ese concepto crucial que aparece como la gran compañera del amor en toda su obra, pero de nuevo lo hará como conocimiento dentro de la duda y de la huida del tiempo: “¿Y si la primavera es verdadera? / Yo no sé qué decir. Me voy alegre. / Tú no sabías que la muerte es bella, / triste doncella."

Igual que en sus cinco libros canónicos la presencia de la alegría en la poesía de Claudio Rodríguez va a ser algo fundamental, en Aventura (Rodríguez, 2004), libro inacabado editado en forma facsimilar después de su muerte, la alegría será uno de los conceptos esenciales, hasta el punto de 
cerrar o abrir algunos de los poemas más relevantes. Así en el primero, "Un deslumbramiento" y cercana al importante mundo de lo sonoro y la palabra vigilante, leemos: “¿Dónde el sonido, / dónde el sentido ahora / de la palabra en vilo / que me daña y me alegra? // [... ] / Ama lo pasajero. Óyelo ahora / cuando suenan las voces, / la alegría que aclara, / ya no sé qué germinación futura.”. Más adelante en "Meditación a la deriva", y próxima a conceptos tan importantes para nuestros dos creadores como son el oficio y lo sagrado, la alegría aparecerá en los versos: "[...] ¿Y cómo ahora/ el fervor, el oficio y el placer, / una visión que nunca es certidumbre, / [...] / me dan como traición, una alegría / que no debo entender? Ya la fe a oscuras, // [...] / ¡Y se rompió el cristal! ¿Dónde la harina / de la oración? ¿Y quién tendrá alegría / sin su ayuda que hiere, sin el friso / de una sorpresa sin espacio y su hondo / relieve en fondo oscuro levemente / dorado? Ahora la vida es vida. / Llega el secreto, lo sagrado. Llega / la aventura, la obra, como en danza / desnuda. Es el origen. [...]”. Es conocido el uso simbólico que en diferentes ocasiones hiciera Claudio Rodríguez con el significado de su nombre; así, acercará a ello la alegría en "El canto de Los", donde la vemos de nuevo al lado del vuelo, además de utilizarla como cierre significativo del poema: "y ahora ando con pies cojos cuando antes / eran ágiles, casi alegres, sin camino / muy cerca de los ríos. [...] / [...] ¿Dónde el vuelo a ala abierta / de la alondra y el mirlo / en la viña recién amanecida? / ¿Dónde la cepa ardida y nueva cuando / hay un destello dentro de la uva, / primera luz que salva? Es la alegría.".

Como podemos ver, la alegría va apareciendo en Claudio Rodríguez como algo vivo y en tránsito, siempre necesario para la aventura, como un concepto esencial para dar viveza y alzar el poema; no en vano, el propio poeta siempre lo definiría como algo en movimiento, en alza, como "un organismo vivo"; de ahí la importancia que para él siempre tuvo la semilla (Ramos de la Torre, 2009: 110-122), lo que se va haciendo, lo seminal y el concepto de simiente. De igual forma, para Baltasar Lobo este concepto de ver la escultura como algo viviente será crucial en el desarrollo de su estilo creativo:

En Lobo esta impresión de vida germinal, que será esencial en su dramaturgia escultórica, es una levadura que hincha la hogaza de piedra, como si, a semejanza de los organismos vivientes, el interior de la masa estuviera habitado por una fogosidad de moléculas que lo infla al límite sin dejar la menor fisura por rellenar, por una actividad embrionaria que empujase sobre la superficie exterior y pugnase por estallar" [...] "una ambición, en la que reconocemos la matriz de toda su obra: la de "decir el origen", lo primordial, en definitiva, lo que las cosas tienen de verdad (Bolaños, 2000: 182)

Siempre hemos defendido la importancia que en nuestro poeta tiene, no solo la originalidad y la excelencia lírica de su poesía, sino también la eficacia de su pensamiento poético centrado en ciertas claves conceptuales fundamentales como la salvación y la aventura; así, y relacionada con el pensamiento, en este libro inacabado pero altamente sugerente, aparecerá la alegría en el poema "A veces", donde las sensaciones son claves para entender esta poesía centrada en el amor: "La melodía y la alegría suave / del tacto de castaña en el invierno / que me dan como fruto malherido. / Cuánta distancia y cuánta cercanía. / ¡Si el pensamiento fuera lo que se ama!”. Y es que este concepto de lo jubiloso es tan importante para él, que en "Y ya no hay viento ni siquiera aire", la verá como algo continuo, fuera del tiempo: "Es la alegría que no tiene tiempo, / el cuerpo sin adiós como ola en cúpula 
/ en los pliegues de sábana sin muerte.". Finalmente en "Sorpresa" se va a convertir en algo realmente esencial que le servirá para comenzar sus reflexiones poéticas, pues sin ella, sin la alegría, ya no habrá pensamiento, sino solo palabras, solo canto: "Si ya la sensación no es alegría / sino dolor que desfigura el rostro, / no solo el alma que va de vacío / Es cuando el pensamiento se hace canto."

\section{La emoción necesaria y la cercanía de la amistad en la creación.}

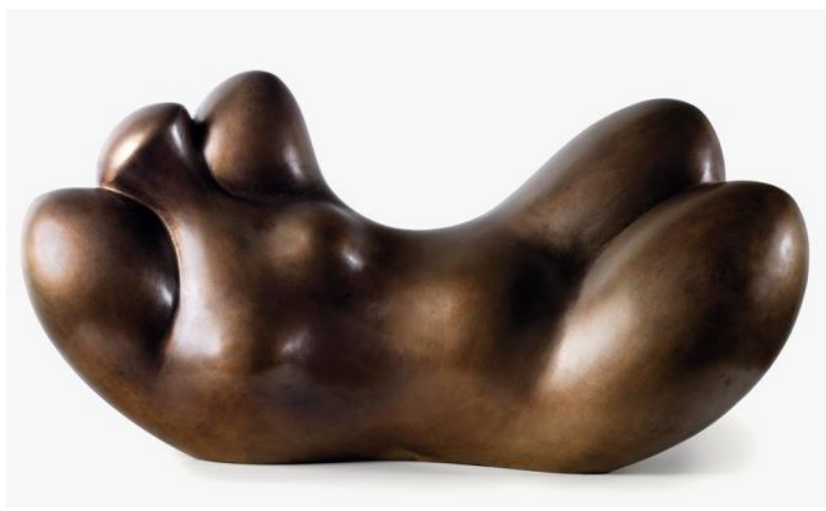

Una vez llegados aquí, hay que decir que además de la alegría, el vuelo y el impulso, marcas fundamentales como ya hemos visto en la cosmovisión de nuestros dos creadores, otra de las claves conceptuales y vitales que les unen o acercan aún más en esta convergencia creativa sobre la que estamos reflexionando, es la importancia que en todo momento, y cada uno por su lado, otorgan a la amistad, a la presencia de personajes cruciales en sus vidas, y la vigencia y la influencia moral que tendrán en ellos. Así, si en Baltasar Lobo hemos mencionado al paso, pero de gran importancia para él, al gran escultor francés Laurens, amigo y mentor de Lobo ${ }^{13}$, sobre cuyo estilo y modo de hacer hablará el zamorano de forma sucinta, admirada, contenida y muy respetuosa en el artículo de agradecimiento y reconocimiento “Quisiera decir algo..." de la revista Le Point en 1946, del que la profesora Bolaños reseña lo siguiente:

$\mathrm{Y}$ a modo de resumen de sus sentimientos concluye su breve disertación con una frase exclamativa, "et toujours! quel grand camarade!", que evoca la complicidad fraterna en torno a un código de valores, que la tímida discreción de ambos pudo impedirles explicitar; y cuyas reglas no escritas estaban inspiradas por la honestidad y la falta de dogmatismo, el nulo gusto por el escándalo, el horror ante todo oportunismo y hasta cierta obstinada lentitud, que es la clave en la fidelidad al oficio.(Bolaños, 2000: 67)

De igual modo, respecto de Lobo, es interesante mencionar al pescador de La Ciotat, quien, siempre cercano, le ayudará a cumplir su necesidad de "salir de las tinieblas", en frase del propio Baltasar, y del que se haría buen compañero de aguas, pesca y contemplación.

$\mathrm{Si}$ al igual que en Lobo y de forma paralela, recordamos la importancia que tiene la amistad en la vida y la obra de Claudio Rodríguez, debemos considerar su gran cercanía con el poeta de Vicente Aleixandre, mentor y amigo, quien en cierto momento de forma epistolar y respecto de esto que venimos comentando le escribe: "Comprendo lo que me dice que quisiera hacer una poesía de impulso. Hay en Ud. un henchimiento, una disposición ascensional en la contemplación de la naturaleza, del

\footnotetext{
${ }^{13}$ Sobre la influencia de Laurens en Lobo conviene recordar las palabras de Lobo: "querría que en mi escultura no se sintiese el esfuerzo, que pareciese simple y natural", una afirmación que traduce ese estado de frescura que tanto admiraba en las esculturas laurensianas, "tan simples, tan claras que nos dan la feliz impresión de que nosotros podríamos hacer lo mismo” (Bolaños, 2000: 153)
} 
mundo en trance de crecimiento" (Cañas, 1987: 100); Eugenio de Luelmo ${ }^{14}$, será igualmente un amigo, un personaje crucial para Claudio Rodríguez, siempre tan unidos en la buena conversación, en el vino de la compañía, y en la presencia del río Duradero.

Sobre están convergencia, tangencialidad o casi semejanza centrada en la amistad, podríamos decir sin temor a equivocarnos, que el papel que en París juega Laurens como amigo, mentor y padre escultórico de Baltasar Lobo, es similar al que ejerce Vicente Aleixandre en Claudio Rodríguez bien de forma epistolar cuando nuestro poeta estaba en Inglaterra, bien en sus muchas conversaciones presenciales; tanto es así, que sobre el nobel sevillano, -como recuerda Dionisio Cañas en el libro que venimos citando-, y en una revista de la primavera de 1987, nuestro poeta de forma emocionada aclara:

Aleixandre no era sólo un amigo. No exagero si digo que fue para mí un padre. Me orientó, no sólo su poesía, sino su persona, su propia vida, sus conversaciones, su postura moral, su compañía, su actitud, sus relaciones, sus detalles, su generosidad, su bondad, su visión tan amplia de la vida humana, de la existencia y, naturalmente, también sus consejos literarios (Cañas, 1987: 60)

Pero hay un personaje, un escultor peculiar, en medio de nuestros dos paisanos, Ramón Abrantes ${ }^{15}$, quien de una manera sencilla, pero crucial, sirve de unión para todo lo que venimos diciendo. Abrantes, escultor zamorano autodidacta y hombre de taller, -de pulso, piedra y talla-, fue amigo de Claudio Rodríguez casi desde la juventud del poeta, y a su vez, amigo de Baltasar Lobo desde 1962, a quien visitará y quedará obnubilado por su obra en su estudio-taller de París en 1976. No podemos obviar aquí, la importancia que el taller de escultura y la amistad duradera con artistas y poetas tuvieron para Claudio Rodríguez, quien cerca de Duero y sobre la creación y la amistad, nombrando a algunos de sus amigos poetas, pintores y escultores, escribe el revelador poema "Blas de Otero en el taller de Ramón Abrantes", donde leemos:

Por ver cómo corre el Duero

y cómo la escayola y el cemento,

cómo el pan, la herramienta

cantando y acusando entre las manos

de Ramón y de Julio, y de Marcelo,

de Tomás y de Antonio,

sobre todo de Eugenio,

estabas.

[...] Ahí, en el taller tuyo estás tallando

(copio tu estilo)

no tan sólo palabras verdaderas

sino también la salvación, la busca

y la protesta. Pasa

el agua, ahí, a dos pasos,

del Duero.

\footnotetext{
${ }^{14}$ Recuérdense aquí los versos del poema homónimo: “[...] y ese gran peligro / de su ternura, de su modo de ir / por las calles, nos daban / la única justicia: la alegría. [...] // [...] Él, cuyo oficio sin horario / era la compañía, ¿cómo iba / a saber que su Duero / es mal vecino? // [...] // [...] Pero / por el ojo de todas las cerraduras del mundo / pasa tu llave, y abre / familiar, luminosa, / y así entramos en la casa / como aquel que regresa de una cita cumplida."

${ }^{15}$ Recuérdese la importancia de este escultor en el poema de Claudio Rodríguez ya citado y dedicado a la poesía y la amistad: "Blas de Otero en el taller de Ramón Abrantes", o en el poema "Cosecha de la materia" (Rodríguez, 1979) dedicado a la de creación escultórica.
} 
Como es sabido, Ramón Abrantes, orgulloso de su amistad con Claudio y a quien nuestro poeta en "Cosecha de la materia" escribiese los versos que citamos a continuación, fue siempre un enamorado de la forma de pensar, del estilo, del pulso y del concepto de escultura de Baltasar Lobo:

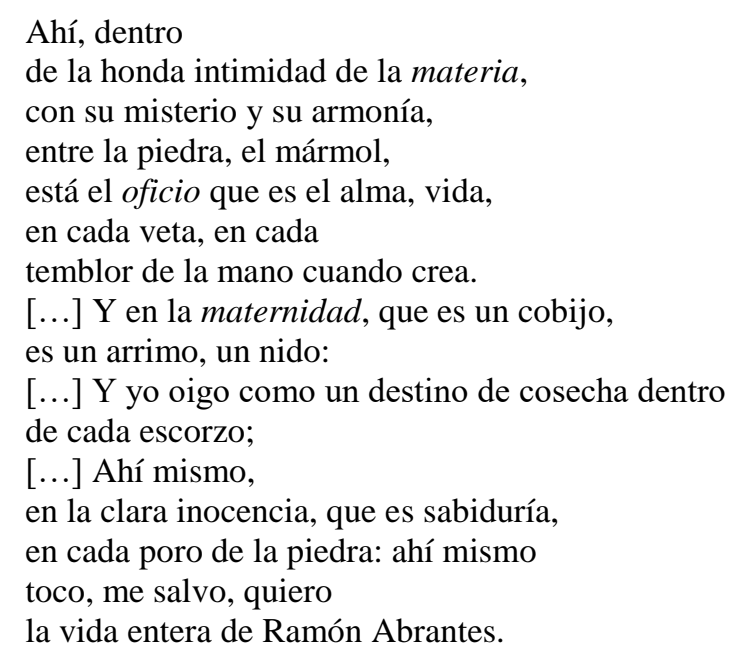

\section{La importancia de lo maternal como fuente creadora.}

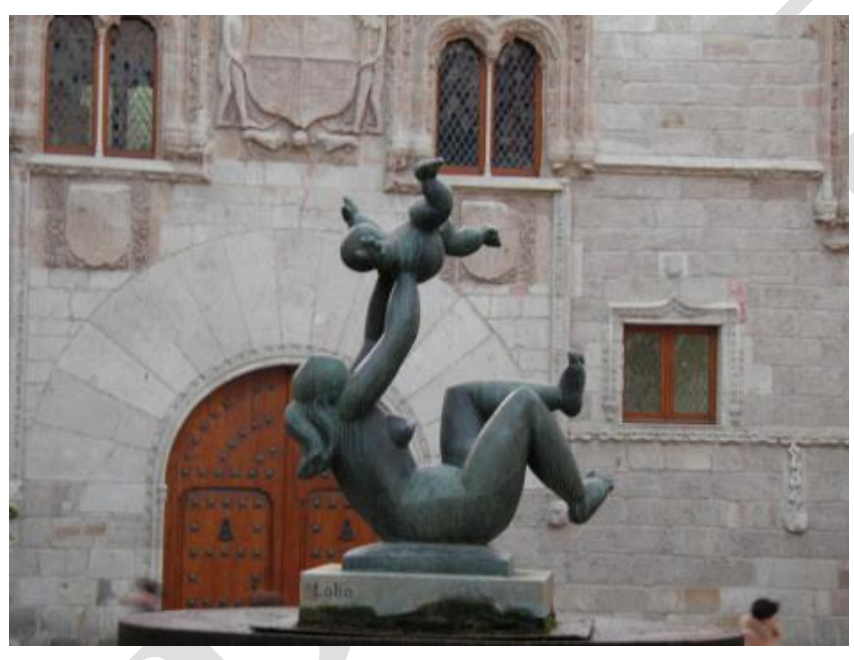

Esta circunstancia, el conocimiento de Laurens, mentor de Baltasar Lobo, y el descubrimiento de numerosos museos, modificarán los planteamientos artísticos de Abrantes y comenzará a trabajar de forma insistente sobre el mundo de lo femenino y el tema de la maternidad entendiendo la escultura como un bloque dinámico y cerrado, y girará, como Lobo, hacia la abstracción.

A través de estas cercanías, comprobamos cómo vuelve a aparecer uno de los ejes de esta tangencialidad que hemos intentado desentrañar a lo largo de nuestras reflexiones, y que conecta a estos dos creadores: la figura de la madre, la maternidad. En este sentido, no podemos olvidar la importancia que estas figuras, la madre, la casa, ${ }^{16}$ y lo familiar ${ }^{17}$ tienen en toda la obra de Claudio

\footnotetext{
${ }^{16}$ El propio poeta dirá sobre esto: “era el paisaje, los amigos, mi casa lo que necesitaba...” (Paulino, 1995: 26)

${ }^{17}$ Respecto de la importancia de la madre, la casa y el mundo de lo familiar puede consultarse el Capítulo II.3: "La casa materna. Desde el origen del amor hacia la necesidad de reubicar el canto" (Ramos de la Torre, 2017: 101 a 139). No obstante, es interesante considerar aquí las apreciaciones del hispanista Philip W. Silver, para quien: "Otro elemento temático importante es el referente al ámbito familiar: la ciudad natal o adoptiva, la casa-nido, la cama, la puerta, los hermanos, la madre, el hogar en fin, como locus amoenus - a despecho de que el hablante sea un flaneur rural y a veces reniegue de la urbe-. En suma, si todo lo relacionado con la familia está aureolado de cierto nimbo mágico, no lo están menos la niñez y la adolescencia ajenas, bañadas en el mismo candor atribuible a todos los orígenes. [...] la región familiar no significa tanto añoranza -antropológica y no personal- de lo prístino, como modelo presente y futuro del ideal social." (Silver, 1985: 235)
} 
Rodríguez ya desde su primer libro Don de la ebriedad, dedicado a su madre; importancia que estará vigente en sentido negativo o positivo en todos los demás libros, hasta llegar al último de los cinco canónicos, Casi una leyenda, en el que la presencia de lo materno y de la casa es esencial; no olvidemos que para Claudio Rodríguez, la casa y la palabra poética están altamente relacionadas:

Cuando se abre una casa, al entrar en ella no se conocen bien las cerraduras, la alondra mañanera que canta en los pliegues de la llave, si hay quicios o aleteos. La casa es necesaria y por eso produce una vivificación, porque es un hogar, un fuego; por ello el canto del poeta es palabra hospitalaria, cercana y lejana aunque siempre deja herida. Y también un sentimiento cotidiano, una presencia de los objetos y de las palabras (Rodríguez, 1992: 28-29)

Así en Casi una leyenda, su presencia será bastante relevante en poemas como "Calle sin nombre", "Nocturno de la casa ida", "Nuevo día", o el importante poema "Lamento Mari” tan cercano al concepto de la Madre-Tierra. ${ }^{18}$

No es este lugar para detenernos a revisar la gran importancia que los mitos tienen para Baltasar Lobo, pero como ya hemos indicado las maternidades aparecen en su escultura como un motivo salvador de reflexión y actuación sobre su situación personal como exiliado:

[...] a Lobo le fascinaba el ciclo de la vida primigenia, la parte eterna de lo femenino, el reino atávico de la Madre y la Diosa, los combates entre criaturas fabulosas y las uniones carnales entre dioses y hombres" [...] "variaciones infinitas en torno a una idea común según la cual la madre y el hijo carecen de rasgos propios porque expresan una totalidad viviente e indivisible, el ciclo universal de la naturaleza, el milagro de la creación. El autor tematiza la plenitud de la vida primordial y a componente animal del vínculo orgánico entre la hembra y sus crías; recoge el mito de la fecundidad en estado puro; tributa un homenaje a la DiosaMadre protectora y nutricia. Madre e hijo son la mejor metáfora de ese continuum matricial que crea una solidaridad esencial entre todo lo que vive (Bolaños, 2000: 165)

Del mismo modo, y en el interesante libro editado con motivo de la $8^{a}$ Bienal de Zamora de 1986 dedicada a la Escultura Ibérica Contemporánea y en la que hay una sección importante dedicada a Baltasar Lobo, el crítico Roy Dolcet explica: "Es en ese sentido en el que la raíz de su obra se convierte en la más fiel representación de las dos fuerzas complementarias y creadoras: la mujer-la fuente maternal, la tierra-la fuerza." (Roy, 1986: 38)

En estas reflexiones, como en Claudio Rodríguez, observamos la necesaria relación entre la madre y el niño, entre estas dos claves conceptuales y creativas de las que venimos hablando y que son tan necesarias para ambos creadores: la maternidad y la infancia, la piedra y la palabra, la escultura y la poesía, el impulso desde la pesantez de la tierra hacia la levedad del aire. Porque, según nos recuerda María Bolaños, desde el principio de la vida y de forma continua existe:

\footnotetext{
${ }^{18}$ Conviene recordar en este sentido la importancia simbólica de la diosa Mari de la que Andrés Ortiz-Osés considerando las palabras de Maimowski dice: "el arquetipo vasco del numen o divinidad matriarcal-femenina Mari, personificación de Ama Lur (Madre Tierra), es nuclear (integra luna y sol femeninos, y «carda» o «rotura» con su mágico peine sagrado las hebras y surcos de un Destino contenido en su brujeril espejo lunar). He aquí que su carácter «monstruoso» para la visión patriarcal-racionalista exige un proceso de iniciación hermenéutica: pues en la imago arquetípica de la diosa vasca Mari tenemos una reminiscencia de los viejos cultos lunar-agrarios a la Diosa Madre protomediterránea, anterior al advenimiento de los cultos patriarcales al sol, la razón y el Ser-Dios celeste ( cultos estos últimos que darán origen a una civilización edípica en la que su propio héroe -Edipo- acaba siendo, como mostrara E. Fromm, víctima expiatoria matriarcal del patriarcalismo occidental y su dramática prohibición -que no articulación- represora del incesto.” (Ortiz-Osés, 1986: 31)
} 
[...] la dependencia esencial de la criatura del cuidado materno o, mejor aún, la importancia decisiva de la madre como condición primera de la vida infantil: la madre es el espacio tridimensional del niño, su campo de existencia, su medio ambiente. La que gobierna su vida y le protege de lo imprevisto.

Y esa relación hecha de impulsos espontáneos, de erotismo muscular, de una pura tensión instintiva, se pone de manifiesto simbólicamente en el juego entre ambos [...] sobre el que se proyectan todos los impulsos de su fantasía instintiva, [...] bien lo alza como si ella misma quisiera echar a volar con la cría entre los brazos (así, en las diferentes versiones de Mére et enfant. La Ciotat, de 1947) o como si fuese a lanzarlo al cielo, mientras el cuerpo infantil se despliega en el aire como un pájaro que planea en el vacío con las alas extendidas, como un nadador imaginario que bate sus remos para no naufragar (Bolaños, 2000: 168)

Estamos, pues, como veíamos al principio de estas reflexiones, no sólo en el territorio del creador, sino en los predios de ese hombre previo al creador que se alimenta de una cultura contextual, de una luz y de un paisaje que lo van conformando y consolidando en él su cosmovisión vital y poética, pues como explica Ortega:

[...] nada humano es eso que es por alguna razón absoluta, sino por la meramente relativa de que antes otro hecho humano de contextura determinada había acontecido. Es, pues, esencial a toda forma de vida humana provenir de otra. De aquí que en la contemplación de un hecho humano nada hay más incongruente que verlo como algo quieto y aislado. [...]Ver algo históricamente es verlo en marcha, proviniendo de una cosa anterior y yendo hacia otra posterior. La pupila de la historia no se detiene nunca, sino que pendula sin cesar hacia delante y hacia atrás, asimilándose de este modo a la realidad que contempla, la cual es, en efecto, un venir de, un ir hacia -y no es otra cosa. (Ortega, 1983. VIII: 658)

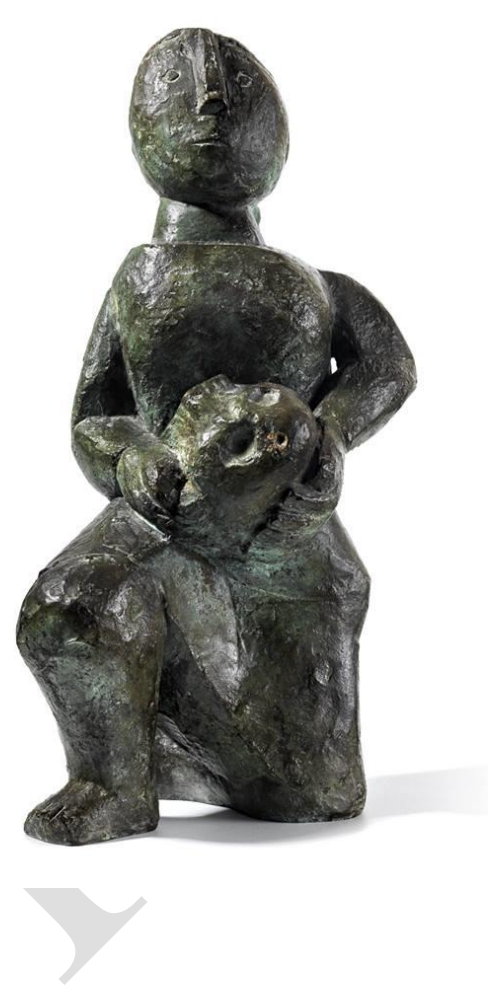

Para terminar este artículo quiero recordar unas reflexiones del propio Claudio Rodríguez, quien sobre este hecho del hombre y su ser creador asegura:

La finalidad de la poesía, como la de todo arte, consiste en revelar al hombre aquello por lo cual es humano, con todas sus consecuencias. Aquí creo conveniente añadir que soy partidario del sentido moral del arte. La validez del arte entraña moralidad [...] La poesía trata de exponer el destino humano en una relación de totalidad con la época en que se produce y con el hombre que la escribe. (Ribes, 1963: 87-92)

Así va a ocurrir con nuestros dos paisanos, en los que la creación, ya sea la escultura o la pintura en el caso de Baltasar Lobo, ya sea la palabra y la poesía, respecto de Claudio Rodríguez, se abre a todos nosotros y nos invita a la admiración, a la participación, a la reflexión y al respeto, hacia unas vidas entregadas a la mejora del hombre, de todos los hombres. 
232 Tropelías. Revista de Teoría de la Literatura y Literatura Comparada, 32 (2019)

Luis Ramos de la Torre

\section{Bibliografía}

ALEIXANDRE, V. (1953): “Carta a Claudio Rodríguez 10-9-1953”, en CAÑAS, D. (1987) Claudio Rodríguez, Ediciones Júcar, p. 100.

BACHELARD, G. (1947): El aire y los ensueños de la voluntad, México, Fondo de Cultura Económica.

- (1965): La poética del espacio, México, Fondo de Cultura Económica.

- (1958): El aire y los sueños, México: Fondo de Cultura Económica. (1994): La tierra y los ensueños de la voluntad, Madrid, F.D.C.

BERGSON, H. (1982): La energía espiritual, Madrid, Espasa Calpe.

BOLAÑOS ATIENZA, M. (2000): El silencio del escultor. Baltasar Lobo (1910-1993), Junta de Castilla y León. León.

BONET, J. M. (2015): "Baltasar Lobo: instantes de felicidad" en Baltasar Lobo en las Cortes de Castilla y León, Cortes de Castilla y León, Valladolid, p. 16.

CALVINO, I. (1989): Seis propuestas para el próximo milenio, Madrid, Siruela.

Del CAMPO, J. (2017): “Baltasar Lobo. Creer; seducir; emocionar", en BALTASAR LOBO Escultura en plenitud, Caja de Burgos, p. 35.

CAÑAS, D. (1987): Claudio Rodríguez, Madrid, Ediciones Júcar.

DAMASIO, A. (2009): En busca de Spinoza, Barcelona, Drakontos.

DIEHL. G. (1995): “Souvenirs, souvenirs” Lobo. Skulpturen. Zurich, Galerie Nathan.

ELGAR. F. (1962): Prefacio al catálogo Lobo. Sculptures, París, Villand\&Galanis.

FERRATER MORA, J. (1991): Diccionario de Filosofía, Barcelona, Círculo de Lectores.

FRACHETTO, G. (2014): Como sentimos, Barcelona, Anagrama.

GUILLÉN, M. (1960): Artistas españoles de la Escuela de París, Madrid, Taurus.

HERNÁNDEZ, J. (1972): "Claudio Rodríguez y la salvación de la materia", El Correo de Zamora, 23 de abril de 1972, p. 12.

IGLESIAS, M. (1989): «[Entrevista a Claudio Rodríguez]», Las tres luces, RNE-Radio 5, Zamora, 16 de septiembre 1989.

LOBO, B. (2018): Documental sobre Baltasar Lobo realizado por HEPKRA Digital S. L. en colaboración con RTVE.

LOBO, V. (1995): Mi hermano Balta. Madrid: Ediciones Libertarias.

MARINA, J. A. (2012): "La alegría", La Vanguardia (12-X-2012), https://www.lavanguardia. com/estilos-de-vida/20121012/54352884050/la-alegria.html (última consulta, 30-4-2019).

ORTEGA Y GASSET, J. (1983): Obras Completas, vol. VIII, Madrid, Alianza Editorial.

ORTIZ-OSÉS, A. (1986): «La interpretación de mitos, relatos y leyendas», aparecido en Revista Anthropos $\mathrm{n}^{\circ}$ 54, (Monográfico dedicado a Andrés Ortiz-Osés), p. 31.

PASTOR, F. (1979): La distancia más corta, Málaga, Publicaciones de la Librería Anticuaria El Guadalhorce (Ilustraciones de Baltasar Lobo). 
(1981): La palabra y otros silencios, Barcelona, La Gaya Ciencia, (Ilustraciones de Baltasar Lobo).

PAUlinO, J. (1995): «Entrevista a Claudio Rodríguez», en Compás de Letras, nº6, junio 1995, Madrid: Universidad Complutense, p. 26.

PRIETO DE PAULA, Á. L. (1980): La llama y la ceniza. Introducción a la poesía de Claudio Rodríguez, Salamanca: Ediciones de la Universidad de Salamanca y Colegio Universitario de Zamora.

(1991): «La noche solar de Claudio Rodríguez» en La lira de Arión (De poesía y poetas españoles del siglo XX), Alicante, Universidad de Alicante y Caja de Ahorros Provincial de Alicante, p. 167.

RAMOS DE LA TORRE, L. (2004): «QQue Claudio la está velando!», en Archipiélago, Revista de Crítica de la Cultura, nº 63 (Monográfico dedicado a Claudio Rodríguez), Madrid.

- (2004): "La infancia como valor en la literatura de Claudio Rodríguez", Primeras Noticias, Revista de Literatura (Especial Literatura y Valores), $\mathrm{n}^{\circ}$ 201, Barcelona, Centro de Comunicación y Pedagogía, pp. 61-69.

(2005): "Visión antropológica de la mano y los oficios en el pensamiento y la poética de Claudio Rodríguez", en Themata, Revista de Filosofía, № 35, Universidad de Sevilla, pp. 509-518.

- (2009): "Presencia de la semilla y lo seminal en la poesía de Claudio Rodríguez", en República de las Letras, no 112, Madrid, Asociación Colegiada de Escritores de España, pp. 110-122.

(2017): El sacramento de la materia (Poesía y salvación en Claudio Rodríguez), Guadalajara, PiEdiciones.

RIBES, F. (1963): «Unas notas sobre poesía», en Poesía última, Madrid: Taurus, pp. 87-92.

RODRÍGUEZ, C. (1979): Poema «Cosecha de la materia» en [Ramón] Abrantes: escultura, [folleto de la exposición] Zamora: Caja de Ahorros y M. P. de Salamanca, diciembre 1979.

_ (1983): "Reflexiones sobre mi poesía”, Madrid, Universidad Autónoma, Escuela de Formación del Profesorado de E.G.B. "Santa María", p. 12.

(1984): "A manera de un comentario" en Desde mis poemas, Madrid, Cátedra, p. 14.

(1986): Poema "Monólogo del escultor" en $8^{a}$ Bienal Ciudad de Zamora, Escultura Ibérica Contemporánea, Junta de Castilla y León-Ayuntamiento de Zamora-Diputación de Zamora, Zamora, p. 27.

(1987): “Leopardi”, en $A B C$, Madrid, 13 de junio de 1987.

(1988): Claudio Rodríguez para niños, Edición preparada por Luis M. GARCÍA JAMBRINA y Luis RAMOS DE LA TORRE, Madrid, Ediciones de la Torre.

(1992): Poesía como participación: hacia Miguel Hernández, Madrid-Zamora, Real Academia de la Lengua- Ayuntamiento de Zamora.

- (2004): "Claudio Rodríguez: El hombre no puede ser libre. Entrevista de Juan Carlos Suñén" en La otra palabra (Escritos en prosa), edición de Fernando YUBERO, Barcelona, Tusquets, p. 233. 
234 Tropelías. Revista de Teoría de la Literatura y Literatura Comparada, 32 (2019)

Luis Ramos de la Torre

(2004): "Claudio Rodríguez o la influencia de todo". Entrevista de Federico Campbell en La otra palabra (Escritos en prosa), p. 226.

(2004): Aventura, Edición facsimilar a cargo de Luis GARCÍA JAMBRINA, Salamanca, Tropismos.

ROY DOLCET, J. (1986): "La escultura como forma de ser, Baltasar Lobo" en $8^{a}$ Bienal Ciudad de Zamora, Escultura Ibérica Contemporánea, p. 38.

SILVER, P. W. (1985): La casa de Anteo, Madrid, Taurus.

VÁZQUEZ PARGA, A. (2009): “Baltasar Lobo" en http://www.culturandalucia.com/baltasar_lobo/ Baltasar_Lobo_ensayo_Ana_Vazquez_Parga.htm (última consulta, 30-4-2019). 